\title{
Particulate pollution in different housing types in a UK suburban
}

\author{
location \\ Zaheer Ahmad Nasir ${ }^{1,2}$ and Ian Colbeck ${ }^{1 *}$ \\ ${ }^{1}$ School of Biological Sciences, University of Essex, Colchester, CO4 3SQ, U K \\ ${ }^{2}$ Healthy Infrastructure Research Centre, Department of Civil, Environmental \& Geomatic \\ Engineering, University College London, London WC1E 6BT, UK
}

Corresponding Author: Ian Colbeck

School of Biological Sciences, Wivenhoe Park, University of Essex, Colchester, CO4 3SQ, United Kingdom

Telephone: 0044-1206-873321

Fax: 0044-1206-872592

e-mail: colbi@essex.ac.uk

Running Title: Particulate matter in residential built environments

Keywords: PM, Mass, Number concentration, Housing, UK 


\begin{abstract}
To investigate the levels of particulate pollution in residential built environments measurements of $\mathrm{PM}_{10}, \mathrm{PM}_{2.5} \mathrm{PM}_{1}$ and concentrations were made between 2004 and 2008 in various residencies in a UK suburban location. Measurements were carried out in three different residential settings (Type I, II and III). In type I non-smoking living rooms, the highest 24-hour mean concentrations were found in summer. When smoking took place in type I residences, the concentrations of $\mathrm{PM}_{10}, \mathrm{PM}_{2.5}$ and $\mathrm{PM}_{1}$, during the winter were almost double those in summer. In type II houses the concentrations were higher in the houses with open plan kitchens than in those with separate kitchens. In type III houses, mean concentrations were significantly higher in wood heated living rooms than those using central heating. In kitchens, cooking resulted in substantially higher concentrations of particulate matter with levels above those in smoking living rooms in winter. The hourly maximum values of number concentration were considerably higher in smoking rooms than nonsmoking ones. Cooking resulted in increased number concentrations, with the average hourly maximum concentration of $179,110 \# / \mathrm{cm}^{3}$. Particle mass and number emission rates were determined for a number of activities. In kitchens grilling had the highest average number emission rate, followed by boiling and frying. The results clearly highlight the impact of different forms of dwelling and their use and management by occupants on the levels of particulate matter in naturally ventilated residential built environments.
\end{abstract}




\section{Introduction}

In developed world, we spend almost $90 \%$ of our time indoors in a variety of built forms (Klepeis et al., 2001). Among these (e.g. residences, offices, schools, transport), the residential built environment is of great importance in terms of contribution to total population exposure to particulate matter due to the amount of time spent there, especially by children and the elderly. In USA, Canada and Germany, studies on time-activity patterns have revealed that the percentage of mean time of stay indoors in the home was $64.97 \%$, 65.94\% and 65.41\%, respectively (Leech et al. 2002; Brasche and Bischof, 2005).

Among the wide variety of contaminants in built environments, air pollutants, especially, particulate matter (PM) is of particular concern owing to its association with cardiopulmonary ailments. Particulate matter is complex matrix of varying size, shapes and chemical composition and once airborne is subject to multiple processes. Furthermore, PM may act as a carrier matrix to a variety of biological contaminants posing a serious threat to an occupant's health and wellbeing. There are numerous indoor sources of PM and identification and assessment of their relative contribution to indoor PM can be a complicated process. It can vary greatly among different residential settings depending upon a number of factors including: the type, nature and number of sources, building characteristics, infiltration or ventilation rates, removal rates, outdoor concentrations and meteorological conditions (Mitchell et al., 2007).

Globally there are noticeable differences in the types and strength of these sources and they are closely linked to socio-economic developments. A number of studies on indoor particulate matter have been carried out within Europe (Gotschi et al., 2002; Janseen et al., 2005; Lai et al., 2006) and a significant variation in their levels observed. With reference to 
the UK, scattered studies on indoor PM have been carried but these were limited either in number of houses or duration. Jones et al. (2000) measured PM inside and outside seven homes within Birmingham and two homes in rural locations. BeruBe et al. (2004) monitored spatial and temporal variations in $\mathrm{PM}_{10}$ mass in six homes in Wales and Cornwall. Their studies showed that there were greater masses of $\mathrm{PM}_{10}$ indoors, and that the composition of indoor $\mathrm{PM}_{10}$ was influenced by outdoor sources. Lai et al. (2006) have reported indoor concentrations of $\mathrm{PM}_{2.5}$, black smoke and $\mathrm{NO}_{2}$ in six European cities: Athens (Greece), Basel (Switzerland), Helsinki (Finland), Milan (Italy), Oxford (UK) and Prague (Czech Republic). They highlighted that socio-economic characteristics of the population, living styles and cultural practices can affect indoor pollution levels. In a related study in Oxford, Lai et al. (2004) reported that levels of $\mathrm{PM}_{2.5}$ were higher for personal and residential indoor exposure $\left(17.4 \mu \mathrm{g} / \mathrm{m}^{3}\right.$ and $\left.17.3 \mu \mathrm{g} / \mathrm{m}^{3}\right)$ than that outdoors $\left(9.1 \mu \mathrm{g} / \mathrm{m}^{3}\right)$. Wigzell et al. $(2000)$ investigated 10 homes in Oxford and quote 48-hour mean concentration of $\mathrm{PM}_{2.5}$ in kitchens and living rooms ranging from 5 to $77 \mu \mathrm{g} / \mathrm{m}^{3}$ and 6 to $71 \mu \mathrm{g} / \mathrm{m}^{3}$ with a mean of $18 \mu \mathrm{g} / \mathrm{m}^{3}$ and $17 \mu \mathrm{g} / \mathrm{m}^{3}$, respectively. Mohammadyan and Ashmore (2005) found that the geometric mean indoor concentration of $\mathrm{PM}_{2.5}$ in homes in Yorkshire was $19 \mu \mathrm{g} / \mathrm{m}^{3}$ with higher values in winter $\left(46 \mu \mathrm{g} / \mathrm{m}^{3}\right)$ than in summer $\left(13.4 \mu \mathrm{g} / \mathrm{m}^{3}\right)$. In Cardiff, O'Connell et al. (2008) carried out an investigation on indoor and outdoor levels of $\mathrm{PM}_{5}$ and total particle number concentration. The median outdoor $\mathrm{PM}_{5}$ concentration in high traffic and low traffic (16.7 $\mu \mathrm{g} / \mathrm{cm}^{3}$ and $\left.11.5 \mu \mathrm{g} / \mathrm{cm}^{3}\right)$ was higher than that indoors $\left(13.2 \mu \mathrm{g} / \mathrm{cm}^{3}\right.$ and $\left.9.4 \mu \mathrm{g} / \mathrm{cm}^{3}\right)$. In a study on indoor air quality in homes of patients with chronic obstructive pulmonary disease in North East Scotland, Osman et al. (2007) reported that average indoor $\mathrm{PM}_{2.5}$ levels were $18 \mu \mathrm{g} / \mathrm{m}^{3}$. In Manchester, a study by Gee et al. (2002) showed that the levels of indoor $\mathrm{PM}_{2.5}$ ( 5 day mean) in living rooms and bedrooms were $28.4 \mu \mathrm{g} / \mathrm{cm}^{3}$ and $19 \mu \mathrm{g} / \mathrm{m}^{3}$, respectively. In London Wheeler et al. (2000) found that indoor levels of $\mathrm{PM}_{10}$ and $\mathrm{PM}_{2.5}$ during winter, 
spring and summer were $29 \mu \mathrm{g} / \mathrm{m}^{3}$ and $54 \mu \mathrm{g} / \mathrm{m}^{3}, 24 \mu \mathrm{g} / \mathrm{m}^{3}$ and $54 \mu \mathrm{g} / \mathrm{m}^{3}, 19 \mu \mathrm{g} / \mathrm{m}^{3}$ and 42 $\mu \mathrm{g} / \mathrm{m}^{3}$, respectively.

Furthermore, knowledge of particulate emissions from indoor sources is increasing. The most important sources include cooking, kerosene heating and wood burning (e.g. Sjaastad and Svendsen, 2008), while sources such as cleaning, dusting and vacuuming, showering, electric motors, movement of people and gas-to-particle conversion have also been investigated (e.g. Abt et al. 2000a and b; Waring et al., 2008). Secondary formation of ultrafines has been observed from chemical reactions between ozone and terpenes (Weschler 2003). In addition, concentration measurements have been carried out for various cooking activities (Hussein et al., 2005) while number concentration emissions have been reported from a clothes dryer (Wallace, 2005), office equipment (He et al., 2007) and vacuuming (Gehin et al., 2008).

While these studies have provided valuable information on indoor particle sources and their concentrations they were limited either in number/types of houses or duration and have mostly focused on mass concentration of $\mathrm{PM}_{10}$ or $\mathrm{PM}_{2.5}$. However, knowledge of the mass concentration of size resolved indoor particulate matter $\left(\mathrm{PM}_{10}, \mathrm{PM}_{2.5}\right.$ and $\left.\mathrm{PM}_{1}\right)$, number concentration and emission rates of different sources in residential built environments is of great importance for the assessment of total human exposure. Moreover, as most of the sources of indoor particles are activity dependent and emissions are episodic, it is reasonable to argue that there would be substantial variation in the concentration of particles and subsequent exposure in various residential buildings. Hence there is a need to determine particulate pollution in different housing types and the relative contribution of different sources to the total exposure of residents in different geographical regions over longer durations. The present study was carried out in a suburban area of South East England in 
different residential types, categorized depending on number of bedrooms and occupant density, to investigate how indoor PM concentrations vary diurnally and seasonally; and to estimate emission strengths of different indoor sources of particulate matter.

\section{Materials and Methods}

\section{Sampling sites (Residential settings)}

Sampling was carried out in three types of residences: A single room in shared multi-storey accommodation (Type I); single bedroom flats in three storey buildings (Type II); and two or three bedroom houses (Type III). The single shared rooms were in student flats of fourteen, five or three storey buildings at the University of Essex, UK. Types II and III residences were located in different parts of Colchester. The overview of sampling location/sites/spaces is provided in Table 1.

\section{Sampling design}

The measurements of mass concentration $\mathrm{PM}_{10}, \mathrm{PM}_{2.5}$ and $\mathrm{PM}_{1}$ in each setting were made continuously for a period of at least two weeks in living rooms and kitchens. However, in some cases these were over a month depending upon the willingness of inhabitants. The number concentration measurements were of $1-3$ week duration and taken in type I living rooms and kitchens and type II kitchens. In all the settings the measurements were made at a height of $1 \mathrm{~m}$. Simultaneous indoor/outdoor measurements were made for $\mathrm{PM}_{10}, \mathrm{PM}_{2.5}$ and $\mathrm{PM}_{1}$ in type I residences for a period of 1 week. Data were collected every minute for all the instruments. The activities of the inhabitants were documented during the sampling periods by $24-$ hr time-activity diaries.

\section{Calculation of air exchange rate and emission rates of various sources}


Information on the air exchange rate is vital in order to calculate the emission rates of different indoor sources. The tracer gas technique was used to measure air exchange rates. Here a tracer gas $\left(\mathrm{CO}_{2}\right)$ was injected into the rooms and its decay rate used to compute air exchange rates. This method involves the following key assumptions: mixing of the tracer gas is uniform, there is no chemical reaction between the tracer gas and surrounding materials, the exfiltration rate of the tracer is constant and no indoor source of the gas is operating (Buonanno et al., 2009; He et al. 2004).

The background level of $\mathrm{CO}_{2}$ was measured in each experimental space for a period of one week by a Gasprobe IAQ 4 with a sampling interval of 1 minute. During the measurements of air exchange rates, $\mathrm{CO}_{2}$ was released so that concentrations were up to three to four times background levels. The inhabitants were not present during the measurements and these were carried out with both open and closed windows. Three measurements were taken at each site on the same day.

The air exchange rates $(\lambda)$ were calculated by using the following equation (Nantka, 1990):

$$
\lambda=\frac{1}{t} \ln \frac{C_{t}}{C_{o}}
$$

Where $\mathrm{t}$ is time, $\mathrm{C}_{\mathrm{t}}$ and $\mathrm{C}_{\mathrm{o}}$ are $\mathrm{CO}_{2}$ concentration at time $\mathrm{t}$ and 0 , respectively.

The emission rates of different indoor sources were calculated following He et al. (2004). The air exchange rates and the emission rates of different indoor sources were calculated only in type I residences.

\section{Instrumentation}

The mass concentration of particulate matter $\left(\mathrm{PM}_{10}, \mathrm{PM}_{2.5}, \mathrm{PM}_{1}\right)$ was monitored using two optical particle counters. The instruments were GRIMM aerosol spectrometers: i) Model 1.108 ii) Model 1.101 (Grimm Aerosol Technik GmbH, Ainring, Germany). The model 1.108 can classify up to 15 size ranges and has a flow rate of $1.2 \mathrm{l} /$ minute. The model 1.101 reports 
only the mass fraction in 3 size distributions and operates at a flow rate of $0.601 /$ minute. For the present study both of spectrometers were used to report mass fraction in the environmental mode $\left(\mathrm{PM}_{10}, \mathrm{PM}_{2.5}, \mathrm{PM}_{1}\right)$. The spectrometers were factory calibrated, prior to the sampling campaign. A gravimetric correlation was carried out with Stearin and an optical calibration cross reference was performed with spherical glass beads with a density of 2.8 $\mathrm{g} / \mathrm{cm}^{3}$ and a refractive index of 1.36 . In addition, a calibration factor was determined for measurements in living rooms where either smokers or wood burning was present. The instruments collect particles on an integrated $47 \mathrm{~mm}$ PTFE-filter in order to calculate a calibration factor. The instruments also keep a record of the total mass collected and air volume sampled. Pre-weighed filters were placed inside the monitors and after each measurement campaign the filters were weighed again to calculate the calibration factor. All the filters were equilibrated before initial and final weighing for a minimum of 24 hours in a controlled environmental chamber. The filters were weighed thrice before and after the sampling using a microbalance. The calibration factors for rooms with smokers and wood burning were $0.90( \pm 0.21)$ and $0.70( \pm 0.09)$, respectively. The concentrations reported by the Grimm were adjusted with these calibration factors. To measure particle concentration, two condensation particle counters were used: TSI model 3781 and 3010 (TSI Incorporated, St. Paul, MN, USA). Temperature, humidity and carbon dioxide was monitored with a Gasprobe IAQ 4 (BW Technologies Ltd, Canada).

\section{Data analysis}

The data were further analysed hourly to investigate the effect of various activities on particulate matter levels and 24 hour mean along with maximum, minimum and standard deviation value were calculated for each sampling space. A paired t-test was undertaken in order to test the difference in the mass concentration of particulate matter in (i) smoking and non-smoking living rooms in type I houses between winter and summer, (ii) in type II houses 
between residences with open plan kitchen and with separate kitchen and (iii) in type III houses between centrally heated and wood burning living rooms during winter. In addition, analysis of variance (ANOVA) was carried out to test the difference in the concentration of $\mathrm{PM}_{10}, \mathrm{PM}_{2.5}$ and $\mathrm{PM}_{1}$ among non-smoking living rooms in type I, II and III houses during winter and post hoc comparisons were carried out. A significance level of 0.05 was used. Statistical analysis was carried out with SPSS (version 16).

\section{Results and discussion}

\section{Mass concentration of particulate matter in living rooms}

\section{Type I residences}

The measurement of mass concentration in type I residences were carried out in smoking and non-smoking living rooms, unoccupied living rooms and electric kitchens. The measurements for non-smoking and smoking rooms were conducted in winter and summer. Furthermore, simultaneous indoor/outdoor measurements in smoking living rooms were carried out during the summer. The results in smoking and non-smoking living rooms are summarised in Table 2. In non-smoking living rooms, the 24 hour concentrations were slightly higher in summer than winter. The increase was more prominent in the case of the fine fraction $\left(\mathrm{PM}_{2.5}, \mathrm{PM}_{1}\right)$ and this indicates the influence of ambient levels and the role of ventilation. In addition, the standard deviation indicates a more stable concentration in summer than winter. It is noteworthy that these living rooms were occupied by a single person and during most of the day were unoccupied. Therefore, it can be argued that under natural ventilation conditions the mass concentration of $\mathrm{PM}_{10}, \mathrm{PM}_{2.5}, \mathrm{PM}_{1}$ and $\mathrm{PM}_{10}-\mathrm{PM}_{2.5}$ in non-smoking living rooms is greatly influenced by outdoor sources. There was no 
statistically significant difference between and winter and summer concentrations. Figures 1 and 2 show the hourly average mass concentration of $\mathrm{PM}_{10}, \mathrm{PM}_{2.5}$ and $\mathrm{PM}_{1}$ in a non-smoking living room during winter and summer, respectively.

The mass concentration of particulate matter in smoking residences during winter and summer clearly highlight the effect of smoking on indoor particulate matter levels and the role of ventilation, as the 24-hour averages values were halved in summer compared to the winter. Most of the particulate mass was centred towards the $\mathrm{PM}_{1}$ size fraction (Table 2). There was statistically significant difference between summer and winter time concentration of $\mathrm{PM}_{10}(\mathrm{t}=-3.973, \mathrm{p}<0.05), \mathrm{PM}_{2.5}(\mathrm{t}=-3.499, \mathrm{p}<0.05), \mathrm{PM}_{1}(\mathrm{t}=-3.327, \mathrm{p}<0.05)$ and $\mathrm{PM}_{10}-$ $\mathrm{PM}_{2.5}(\mathrm{t}=-4.498, \mathrm{p}<0.05)$. Figures 3 and 4 not only show the impact of smoking on PM levels but also reflect that background values were higher in winter than in summer.

Furthermore, comparison of smoking and non-smoking residences revealed that during the summer concentrations of $\mathrm{PM}$, particularly $\mathrm{PM}_{2.5}$ and $\mathrm{PM}_{1}$ were higher in living rooms with smokers than non-smokers (Table 2). However there was no statistically significant difference in mass concentration between smoking and non-smoking residences. Only $\mathrm{PM}_{1}$ was significant at $\mathrm{p}=0.08(\mathrm{t}=-2.577)$. In contrast, during winter a statistically significant difference was documented between smoking and non-smoking residences for $\mathrm{PM}_{10}(\mathrm{t}=-$ 3.111, $\mathrm{p}<0.05), \mathrm{PM}_{2.5}(\mathrm{t}=-3.222, \mathrm{p}<0.05)$ and $\mathrm{PM}_{1}(\mathrm{t}=-3.394, \mathrm{p}<0.05)$. The significantly higher levels of PM in smoking living rooms during winter are likely due to reduced ventilation. Several studies have shown an association between smoking and particulate matter, especially $\mathrm{PM}_{2.5}$, in houses. Jones et al. (2000) measured $\mathrm{PM}_{10}$ in the homes of smokers and daily means in the range 27 to $88 \mu \mathrm{g} / \mathrm{m}^{3}$. Concentrations in the present study are 
comparable with the lower end of this range. Non-smoking homes in the same investigation had higher concentrations than those for living rooms in type I residences in the current study. Recently Raaschou-Nielsen et al. (2011) reported that $\mathrm{PM}_{2.5}$ levels were 2.8 times higher in houses where people smoked. Our results indicate that maximum hourly concentrations can be up to 13 times higher. The measurements by Raaschou-Nielsen et al. (2011) were made in bedrooms, some distance from the smoking, whereas our measurements were made in the actual room where smoking was taking place.

In order to understand the effect of human presence /activities on indoor particulate a twoweek measurement campaign was carried out in an unoccupied type I living room. The 24 hour mass concentrations of $\mathrm{PM}_{10}, \mathrm{PM}_{2.5}, \mathrm{PM}_{1}$ and $\mathrm{PM}_{10}-\mathrm{PM}_{2.5}$ were $7 \mu \mathrm{g} / \mathrm{m}^{3}, 7 \mu \mathrm{g} / \mathrm{m}^{3}, 5$ $\mu \mathrm{g} / \mathrm{m}^{3}$ and $1 \mu \mathrm{g} / \mathrm{m}^{3}$, respectively. Comparison of these results with non-smoking, summer time, living rooms in the same type of accommodation revealed that the concentration of $\mathrm{PM}_{10}$ was roughly $50 \%$ lower in unoccupied rooms. Concentrations of $\mathrm{PM}_{2.5}$ and $\mathrm{PM}_{1}$ were only marginally lower in unoccupied rooms. This suggests that in non-smoking living rooms indoor activities generally contribute towards the coarse fraction while, in the absence of indoor sources, the fine fraction is introduced from outdoors.

\section{Type II residences}

Table 3 shows the 24-hour average mass concentration of particulate matter in living rooms in type II residences. The houses sampled differed in their lay out: some with open plan kitchens and others with a separate kitchen. The concentrations were higher in homes with an open plan kitchen, adjacent to the living room, as compared to the homes which had separate kitchens. It is likely that due to the open plan space configuration the concentration in the 
living room was influenced by cooking activities from the kitchen. It is of note there is growing trend of open plan layout primarily driven by a reduction in overall size (floor area) of houses. Currently, in UK, there are no mandatory regulations on minimum space standards and generally, for housing statistics, planning and housing sales the number of bedrooms are being used rather than floor area. For instance, a report by Greater London Authority (2010), on proposed housing design standards, cited that size of the average one-bed flat had reduced by $13 \%$ since 2000 . These changes in interior space configuration along with construction of airtight built environments may enhance the inhabitant's risk of exposure to particles. Although houses with open plan kitchens were non-smoking the relatively higher PM levels, especially in the fine fraction, in living rooms suggest the major contribution was from the kitchen as peak levels were generally correlated with cooking (Figure 5). On the other hand, this phenomenon was not observed in homes with separate kitchen and concentrations were more affected by presence/physical activities (occasional smoking) of the occupants. Nonetheless, there was no statistical evidence to suggest that 24 hour mass concentrations were different between houses with open plan kitchens and those with separate kitchens.

\section{Type III residences}

In type III residences the measurements were made only during the winter and one of the homes used wood for heating while others had central heating. Therefore the results were calculated for houses with and without wood-heating (Table 4). The concentration of particulate matter was considerably higher in wood-heated rooms as compared to centrally heated rooms. There were intermittent periods of very high particulate matter depending upon the usage of the fire place (Figure 6). A statistically significant difference was found between

centrally heated and wood burning living rooms for $\mathrm{PM}_{10}(\mathrm{t}=-5.403, \mathrm{p}<0.05), \mathrm{PM}_{2.5}(\mathrm{t}=-$ 
5.957, $\mathrm{p}<0.05)$ and $\mathrm{PM}_{1}(\mathrm{t}=-6.069, \mathrm{p}<0.05)$. However, there was no significant difference in the case of the coarse size fraction $\left(\mathrm{PM}_{10}-\mathrm{PM}_{2.5}\right)$.

Overall, among the three housing types, the 24-hour mean concentrations in type III living rooms (centrally heated) rooms were higher than type I (non-smoking) and II living rooms. The striking difference was the higher levels of the coarse size fraction in type III living rooms (Figure 7). The results of ANOVA showed that mass concentration of all the size fractions $\left(\mathrm{PM}_{10}, \mathrm{PM}_{2.5}, \mathrm{PM}_{1}\right.$ and $\left.\mathrm{PM}_{10}-\mathrm{PM}_{2.5}\right)$ were significantly different $(\mathrm{F}=9.302$; $\mathrm{F}=4.134 ; \mathrm{F}=4.983 ; \mathrm{F}=17.013$, respectively) at a $\mathrm{p}$ value of 0.05 , among type I, II and III houses. A further post-hoc analysis revealed that $\mathrm{PM}_{10}$, and $\mathrm{PM}_{10}-\mathrm{PM}_{2.5}$ were significantly different among all the housing types, while $\mathrm{PM}_{2.5}$ and $\mathrm{PM}_{1}$ were different between types I and III. The significant difference in coarse size fraction reflects the impact of differing occupancy and varied use and management of housing space by the inhabitants.

\section{Indoor/outdoor concentration of particulate matter}

Tables 5 shows the results of 24 hour mean indoor/outdoor $\mathrm{PM}_{10}, \mathrm{PM}_{2.5}, \mathrm{PM}_{1}$ and $\mathrm{PM}_{10}-$ $\mathrm{PM}_{2.5}$, respectively for a living room (Type I) where smoking occurred. The largest ratios were seen for $\mathrm{PM}_{2.5}$ and $\mathrm{PM}_{1}$, while the coarse fraction showed little change. Generally, indoor concentrations were well correlated with those outdoors but the substantially higher concentration of particulate matter, during smoking, result in indoor/outdoor (I/O) values significantly greater than 1 (Figure 8). Jones et al. (2000) showed that that the daily mean I/O ratio of $\mathrm{PM}_{10}$ in rural homes ranged from 1.8 - 2.9. In USA, Minneapolis-St. Paul metropolitan area a study by Adgate et al. (2003) showed that in non-smoking residences the mean I/0 ratio was 1.6. Recently in a review on relationship between indoor and outdoor particles Chen and Zhao (2011) concluded that the value varies enormously and it is not easy 
to draw uniform conclusions. During the present study daily mean PM10 I/O values were in the range of $0.76-2.83$ (Table 5)

\section{Mass concentration of particulate matter in kitchens}

The results of mass concentrations in the kitchens of type I, II and III residences are summarized in Table 6. The kitchens in type I and II were fitted with electrical cooking appliances. Activities in these typically involved grilling and frying. The effect of cooking is evident in Figure 9. By separating cooking from non-cooking occasions it was found that cooking increases the 24 hour $\mathrm{PM}_{10}, \mathrm{PM}_{2.5}$ and $\mathrm{PM}_{1}$ levels by a factor of approximately 5, 6 and 7 respectively. This is comparable to the figure reported by See and Balasubramanian (2008) for $\mathrm{PM}_{2.5}$ during gas cooking. The 24-hour average concentration in the kitchens of housing types I and II was similar (Table 6). Although the type II kitchen was used by a single couple, the cooking involved extensive frying every day. Furthermore, bread was made once a day in a pan with light oil (bread making by this method produces smoke). Figure 10 clearly reflects the effect of cooking on indoor mass concentration of fine particles. The kitchens in type III accommodation had gas cookers and the 24-hour average concentration of $\mathrm{PM}_{10}, \mathrm{PM}_{2.5}$ and $\mathrm{PM}_{1}$ was lower than in type I and II kitchens. Although the coarse size fraction was higher in type III kitchens. On the whole, the maximum concentrations of PM were recorded in type I kitchens followed by type II and III. Most of mass was centred in the $\mathrm{PM}_{2.5}$ and $\mathrm{PM}_{1}$ size fraction in type I and type II kitchens. Extensive frying and grilling, leading to smoke, in these kitchens could be the likely reason for the high fine fraction. The observed differences in kitchens are very likely due to the differences in frequency/type of cooking and size of kitchens. It is of note that type I kitchens had the maximum cooking frequency as compared to type II and III kitchens. 


\section{Air exchange rates}

Ventilation rates were higher when the windows were open rather than closed. The rates were also more stable when the windows were closed. In living rooms the mean air exchange rate $(\mathrm{ACH})$ with an open window was $2.44( \pm 1.28, \mathrm{n}=10)$ in comparison to $0.30 \mathrm{ACH}( \pm 1.28$, $\mathrm{n}=10)$ when closed. In kitchens, during open windows, the mean rate was $9.04 \mathrm{ACH}( \pm 3.61$, $\mathrm{n}=10$ ). These ventilation rates only reflect the air exchange rates in living rooms and kitchens and the whole house ventilation rates would be different. Knowledge of ventilation rates in residential built environments in the UK is scanty. The available information lends support to the assumption that a large percentage of dwellings could be under-ventilated and the use and management of the residential built environment by occupants greatly impacts on the ventilation performance (Dimitroulopoulou et al., 2005; Aizlewood and Dimitroulopoulou, 2006). It is worth mentioning that the current focus to reduce $\mathrm{CO}_{2}$ emissions from built environments has led to the introduction of energy efficient designs with airtight structures and this may result into further reduction in ventilation rates. In a recent review on ventilation in European dwellings Dimitroulopoulou (2011) concluded that although ventilation has been recognised as an important component of healthy housing in practice a large proportion of dwellings in Europe are under-ventilated (lower than $0.5 \mathrm{~h}^{-1}$ ). It has also highlighted that poor use and lack of knowledge about mechanical ventilation systems among inhabitants of energy efficient homes might result in reduced ventilation.

\section{Number concentration of particulate matter}

In type I residences number concentration measurements were carried out in smoking, nonsmoking, unoccupied living rooms and kitchens (electric). Details of the results are given in Table 7. The measurements in non-smoking living rooms were carried out in March with closed windows. For rooms where smoking took place, hourly maximum values were much 
higher than those in non-smoking rooms. The hourly maximum values reflect the effect of smoking and the hourly minimum can be taken as background values. The measurements in smoking living rooms were made in April/May and the window remained open all the times. This results in greater ventilation in smoking than non-smoking living rooms. In an unoccupied living room the window was open during the period of measurement and comparison of these values with occupied living rooms highlights the influence of human activities .The daily mean values in the unoccupied rooms were close to the average hourly minimum in both smoking and non-smoking living rooms. The kitchens were shared by $5-8$ students and 3 - 4 meals were cooked per day. Grilling, boiling and frying were the main types of cooking, sometimes simultaneously. During various events of cooking the number concentration rose substantially and a maximum hourly concentration of $502,650 \mathrm{\#} / \mathrm{cm}^{3}$ was obtained.

In type II residences the measurements were made only in the kitchen. Due to the lack of 24hour measurements in type II kitchens a direct comparison cannot be made with type I kitchens. However, the maximum hourly in type I reflects the concentration during cooking events and the average hourly maximum was substantially higher in type I kitchens than type II. The frequency and type of cooking are likely factors responsible for this. In type II kitchens frying was predominantly carried out.

Morawska et al. (2003) reported that the 24-hour average number and mass concentrations in kitchens during indoor activities were $18,200 \# / \mathrm{cm}^{3}$ and $15.5 \mu \mathrm{g} / \mathrm{m}^{3}$ and during no activities the respective values were $12,400 \# / \mathrm{cm}^{3}$ and $11.1 \mu \mathrm{g} / \mathrm{m}^{3}$. The 24-hour average number concentration in the present study was higher than that in their study. However, taking the 24hour average minimum value in the present study as an average of no activity periods, the 
values are in good agreement. Hussein et al. (2006) reported that smoking one cigarette in a room increased the number concentration to $36,000 \# / \mathrm{cm}^{3}$ from a background value of 6,000 $\# / \mathrm{cm}^{3}$. In the present study the average hourly maximum number concentration during smoking was $47265 \# / \mathrm{cm}^{3}$. A wide variation in number concentration during various indoor activities has been reported and housing characteristics, occupants' life styles and types of activities/sources all play a pivotal role in indoor particulate matter concentrations.

\section{Impact of activities on indoor PM levels and emission rates of various activities.}

Figure 11 shows the average maximum concentration of $\mathrm{PM}_{10}, \mathrm{PM}_{2.5}$ and $\mathrm{PM}_{1}$ during different activities in houses. Smoking and wood burning for heating in living rooms and cooking involving frying and grilling in kitchens lead to elevated PM concentrations in the fine size fraction, while movement and cleaning contributed to the coarse size. The concentrations during the various activities were highly variable, as evident from high values of standard deviation, most probably due to differences in duration and strength of sources, ventilation, level of air mixing and removal rates. Table 8 presents the emission rates for various activities. A number of factors, such as the actual activity, flooring types, dust loading, carpet age and relative humidity influence PM emissions due to movement (Cheng et al., 2010). Raaschou-Nielsen (2011) reported that vacuuming could increase indoor $\mathrm{PM}_{2.5}$ concentrations by a factor of 1.3 while Corsi et al. (2008) found an increase of $17 \mu \mathrm{g} / \mathrm{m}^{3}$ in $\mathrm{PM}_{10}$. It is expected that resuspension of particles by mechanical agitation may contribute to $\mathrm{PM}_{10}$ emissions during vacuuming. However large PM could be collected on the internal filter whereas the fine size fraction may not be. It has been suggested that emissions from the motor are a source of ultrafine particles (Afshari et al., 2005). It must be remembered that vacuum cleaners have a range of efficiencies and so the emission rate for vacuuming will be dependent on the model of vacuum cleaner used. The $\mathrm{PM}_{2.5}$ emission rate shown in Table 8 is 
broadly consistent with previous reports. In the kitchen (electrical) all the types of cooking contributed significantly to the fine fraction. Other studies have shown that grilling is associated with particularly high levels of PM (He et al., 2004; Raaschou-Nielsen et al., 2011). Many of the published measurements of emission factors for cigarettes are based on machine smoked or chamber experiments and emission factors are in the range of 0.76 $\mathrm{mg} / \mathrm{min}$ (Klepeis et al., 2003) to $7 \mathrm{mg} / \mathrm{min}$ (Ott et al., 1992). Recently, Jiang et al. (2011) reported that emission rate for cigarette smoke was $2.8 \mathrm{mg} / \mathrm{min}$. The mass emission rates of smoking during our study were higher than those reported by $\mathrm{He}$ et al. (2004) where the median emission rate of $\mathrm{PM}_{2.5}$ was $0.99 \mathrm{mg} / \mathrm{min}$. In contrast, the emission rates during frying and grilling were lower than those of $\mathrm{He}$ et al. (2004) who found $2.68 \mathrm{mg} / \mathrm{min}$ and 2.78 $\mathrm{mg} / \mathrm{min}$ respectively. The particle number emissions rates for a number of activities are shown in Table 8 and are comparable to those of Glytsos et al. (2010). The cigarette emission rates are similar to those of Wallace and Ott (2011). It should be remembered that the various reported emission rates have been based on different methods and cover slightly different size ranges. The emission rate determined from an instrument with a minimum detectable particle diameter of $2.5 \mathrm{~nm}$ will be higher than that from one of $20 \mathrm{~nm}$. The instruments used in the current study had minimum detectable particle diameters of $6 \mathrm{~nm}$ (model 3781) and $10 \mathrm{~nm}$ (model 3010). Gehin et al. (2008) report emission rates for particles with diameter between 5 $\mathrm{nm}$ to $1 \mu \mathrm{m}$ while that of Wallace et al. (2008) is for the size range 2 to $64 \mathrm{~nm}$. Buonanno et al. (2009) concluded that the type of the food, oil, cooking style and stove have a significant effect on emissions. This could explain the lower emission, of the order of $10^{11} \mathrm{particles} / \mathrm{min}$, in the current study. Variation in emission rates can result, not only from actual changes in emissions, but also due to the method used to calculate them. Often it assumes instantaneous mixing as well as constant emission rates, air change rates and deposition rates. Emission 
rates in the literature often appear to be dependent on the time spent cooking; short cooking periods produce higher rates than longer cooking periods.

\section{Conclusions}

The present study showed that the concentration of particulate matter in different residence types varies considerably depending on the dwelling types and their use and management by occupants in each setting. Various indoor activities lead to elevated levels of indoor particulate matter. Overall, in terms of housing types, the results of this study reflect that, in the absence of smoking and wood burning fire places, there was a trend of increase in PM concentration with an increase in house size and relative occupancy. Nevertheless the volume of the house, individualistic activities/choices of the inhabitants and ventilation rates can have an overwhelming effect on the concentration of indoor particulate matter. Higher PM concentrations were found in houses with open plan kitchens. At present there is an increasing trend in smaller size dwellings with an open plan space configuration which in the presence of indoor pollution sources may result into enhanced exposure to particulate matter. In general, the results suggest that relatively intermittent indoor activities have a significant effect on the particulate matter in the residential microenvironment. Indoor source strengths from human activities can be large enough to significantly affect human exposure to $\mathrm{PM}_{1}$, $\mathrm{PM}_{2.5}$ and $\mathrm{PM}_{10}$. The doubling of concentration of particulate matter in smoking residences, from winter to summer, highlights the role of inhabitant personal activities/life style and ventilation. Although, the ventilation mechanisms may be intrinsic/design specific in residential built environments their use is largely dependent on the inhabitants' behaviour which may be influenced by climatic conditions, physiological and psychological needs, air hygiene awareness, perception of security, and many socio-demographic factors. Hence, the measurements at a specific geographic location in a specific residential built form may not 
provide reliable information to estimate population exposure to PM. It is important that buildings achieve a high level of airtightness in order to maintain energy efficiency and provide comfort for occupants. This would also reduce the ingress of outdoor particles but could also result in higher exposure to particles generated indoors. There is pressing need to increase public awareness as to the impact of various indoor activities on indoor fine particulate matter and the role of ventilation in maintaining air health. This may improve the environmental health of built environments beyond that of reducing particulate pollution.

\section{REFERENCES}

Abt, E., Suh, H.H., Allen, G., Koutrakis, P., 2000a. Characterization of indoor particle sources: A study conducted in the metropolitan Boston area. Environmental Health Perspectives 108, 35-44.

Abt, E., Suh, H.H., Catalano, P., Koutrakis, P., 2000b. Relative contribution of outdoor and indoor particle sources to indoor concentrations. Environmental Science \& Technology 34, 3579-3587.

Adgate, J.L., Ramachandran, G., Pratt, G.C., Waller, L.A., Sexton, K., 2003. Longitudinal variability in outdoor, indoor, and personal PM2.5 exposure in healthy non-smoking adults. Atmospheric Environment 37, 993-1002.

Afshari, A., Matson, U., Ekberg, L.E., 2005. Characterization of indoor sources of fine and ultrafine particles: a study conducted in a full-scale chamber. Indoor Air 15, 141-150.

Aizlewood, C., Dimitroulopoulou, C., 2006. The HOPE project: The UK experience. Indoor and Built Environment 15, 393-409.

BeruBe, K.A., Sexton,K.J., Jones, T.P., Moreno, T., Anderson,S., Richard, R.J., 2004. The spatial and temporal variations in $\mathrm{PM}_{10}$ mass from six UK homes. Science of the Total Environment 324, 41-53.

Brasche, S., Bischof, W., 2005. Daily time spent indoors in German homes - Baseline data for the assessment of indoor exposure of German occupants. International Journal of Hygiene and Environmental Health 208, 247-253.

Buonanno, G., Morawska, L., Stabile, L., 2009. Particle emission factors during cooking activities. Atmospheric Environment 43, 3235-3242.

Chen, C., Zhao, B., 2011. Review of relationship between indoor and outdoor particles: I/O ratio, infiltration factor and penetration factor. Atmospheric Environment 45, 275-288.

Cheng, K.-C., Goebes, M.D., Hildemann, L.M., 2010. Association of size-resolved airborne particles with foot traffic inside a carpeted hallway. Atmospheric Environment 44, 20622066. 
Colbeck, I., Nasir, Z.A., 2010. Indoor Air Pollution In: Human exposure to pollutants via dermal absorption and inhalation. Edited by Lazaridis, M and Colbeck, I. pp 41-72, Springer

Corsi, R.L., Siegel, J.A., Chiang, C., 2008. Particle resuspension during the use of vacuum cleaners on residential carpet. Journal of Occupational and Environmental Hygiene 5, 232238.

Dimitroulopoulou, C., 2012. Ventilation in European dwellings: A review. Building and Environment 47, 109-125.

Dimitroulopoulou, S., Crump, D., Coward, S., Brown, V., Squire, R., Mann, H., White, M., Pierce, B., Ross, D., 2005. Ventilation, air tightness and indoor air quality in homes in England built after 1995, BRE report BR 477 BRE Garston.

Gee, I.L., Stewart, L., Waston, A.F.R., Fletcher, G., Niven, R., 2002. Indoor air quality in smoking and non-smoking households. Proceedings Indoor Air, 2:512-7

Gehin, E., Ramalho, O., Kirchner, S., 2008. Size distribution and emission rate measurement of fine and ultrafine particle from indoor human activities. Atmospheric Environment 42, $8341-8352$.

Glytsos, T., Ondracek, J., Dzumbova, L., Kopanakis, I., Lazaridis, M., 2010. Characterization of particulate matter concentrations during controlled indoor activities. Atmospheric Environment 44, 1539-1549.

Gotschi, T., Oglesby, L., Mathys, P., Monn, C., Manalis, N., Koistinen, K., Jantunen, M.J., Hänninen, O., Polanska, L., Künzli, N., 2002. Comparison of black smoke and $\mathrm{PM}_{2.5}$ levels in indoor and outdoor environments of four European cities. Environmental Science and Technology 36, 1191-1197.

Greater London Authority, 2010. Overcrowding in social housing. A London action plan. Greater London Authority, London.

He, C., Morawska, L., Taplin, L., 2007. Particle emission characteristics of office printers. Environmental Science \& Technology 41, 6039-6045.

He, C.R., Morawska, L.D., Hitchins, J., Gilbert, D., 2004. Contribution from indoor sources to particle number and mass concentrations in residential houses. Atmospheric Environment $38,3405-3415$.

Hussein, T., Glytsos, T., Ondracek, J., Dohanyosova, P., Zdimal, V., Hameri, K., Lazaridis, M., Smolik, J., Kulmala, M., 2006. Particle size characterization and emission rates during indoor activities in a house. Atmospheric Environment 40, 4285-4307.

Hussein, T., Hameri, K., Heikkinen, M.S.A., Kulmala, M., 2005. Indoor and outdoor particle size characterization at a family house in Espoo-Finland. Atmospheric Environment 39, 3697-3709.

Janssen, N.A.H., Lanki, T., Hoek, G., Vallius, M., de Hartog, J.J., Van Grieken, R., Pekkanen, J., Brunekreef, B., 2005. Associations between ambient, personal, and indoor exposure to fine particulate matter constituents in Dutch and Finnish panels of cardiovascular patients. Occupational and Environmental Medicine 62, 868-877.

Jiang, R. T., Acevedo-Bolton, V., Cheng, K. C., Klepeis, N. E., Ott, W. R., Hildemann, L. M., 2011. Determination of response of real-time SidePak AM510 monitor to secondhand smoke, other common indoor aerosols, and outdoor aerosol. Journal of Environmental Monitoring 13, 1695-1702. 
Jones, N.C., Thornton, C.A., Mark, D., Harrison, R.M., 2000. Indoor/outdoor relationships of particulate matter in domestic homes with roadside, urban and rural locations. Atmospheric Environment 34, 2603-2612.

Klepeis, N.E., Apte, M.G., Gundel, L.A., Sextro, R.G., Nazaroff, W.W., 2003. Determining size-specific emission factors for environmental tobacco smoke particles. Aerosol Science and Technology 37, 780-790.

Klepeis, N.E., Nelson, W.C., Ott, W.R., Robinson, J.P., Tsang, A.M., Switzer, P., Behar, J.V., Hern, S.C., Engelmann, W.H., 2001. The National Human Activity Pattern Survey (NHAPS): a resource for assessing exposure to environmental pollutants. Journal of Exposure Analysis and Environmental Epidemiology 11, 231-252.

Lai, H.K., Bayer-Oglesby, L., Colvile, R., Gotschi, T., Jantunen, M.J., Kunzli, N., Kulinskaya, E., Schweizer, C., Nieuwenhuijsen, M.J., 2006. Determinants of indoor air concentrations of PM2.5, black smoke and NO2 in six European cities (EXPOLIS study). Atmospheric Environment 40, 1299-1313.

Lai, H.K., Kendall, M., Ferrier, H., Lindup, I., Alm, S., Hanninen, O., Jantunen, M., Mathys, P., Colvile, R., Ashmore, M.R., Cullinan, P., Nieuwenhuijsen, M.J., 2004. Personal exposures and microenvironment concentrations of PM2.5, VOC, NO2 and $\mathrm{CO}$ in Oxford, UK. Atmospheric Environment 38, 6399-6410.

Leech, J.A., Nelson, W.C., Burnett, R.T., Aaron, S., Raizenne, M.E., 2002. It's about time: A comparison of Canadian and American time-activity patterns. Journal of Exposure Analysis and Environmental Epidemiology 12, 427-432.

Mitchell, C.S., Zhang, J.J., Sigsgaard, T., Jantunen, M., Lioy, P.J., Samson, R., Karol, M.H., 2007. Current state of the science: Health effects and indoor environmental quality. Environmental Health Perspectives 115, 958-964.

Mohammadyan, M., Ashmore M., 2005. Personal exposure and indoor $\mathrm{PM}_{2.5}$ concentrations in an urban population. Indoor and Built Environment 14, 313-320.

Morawska, L., He, C.R., Hitchins, J., Mengersen, K., Gilbert, D., 2003. Characteristics of particle number and mass concentrations in residential houses in Brisbane, Australia. Atmospheric Environment 37, 4195-4203.

Nantka, M., 1990. Comparison of different methods for air tightness and air change rate determination, in: Sherman, M.H. (Ed.), Air change rate and air tightness in buildings. American Society for Testing and Materials, Philadelphia, pp. 267-282.

O'Connell, S., Au-Yeung, H.-K.C., Gregory, C.J., Matthews, I.P., 2008. Outdoor and indoor respirable air particulate concentrations in differing urban traffic microenvironments. Journal of Toxicology and Environmental Health-Part a-Current Issues 71, 1069-1072.

Osman, L.M., Douglas, J.G., Garden, C., Reglitz, K., Lyon, J., Gordon, S., Ayres, J.G., 2007. Indoor air quality in homes of patients with chronic obstructive pulmonary disease. American Journal of Respiratory and Critical Care Medicine 176, 465-472.

Ott, W.R., Langan, L., Switzer, P., 1992. A time series model for cigarette smoking activity patterns: Model validation for carbon monoxide and respirable particles in a chamber and an automobile. Journal of Exposure Analysis and Environmental Epidemiology 2, 175-200.

Raaschou-Nielsen, O., Sorensen, M., Hertel, O., Chawes, B.L.K., Vissing, N., Bonnelykke, K., Bisgaard, H., 2011. Predictors of indoor fine particulate matter in infants' bedrooms in Denmark. Environmental Research 111, 87-93. 
See, S.W., Balasubramanian, R., 2008. Chemical characteristics of fine particles emitted from different gas cooking methods. Atmospheric Environment 42, 8852-8862.

Sjaastad, A.K., Svendsen, K., 2008. Exposure to mutagenic aldehydes and particulate matter during panfrying of beefsteak with margarine, rapeseed oil, olive oil or soybean oil. Annals of Occupational Hygiene 52, 739-745.

Wallace, L., 2005. Ultrafine particles from a vented gas clothes dryer. Atmospheric Environment 39, 5777-5786.

Wallace, L., Ott, W., 2011. Personal exposure to ultrafine particles. Journal of Exposure Science and Environmental Epidemiology 21, 20-30.

Wallace, L., Wang, F., Howard-Reed, C., Persily, A., 2008. Contribution of gas and electric stoves to residential ultrafine particle concentrations between 2 and $64 \mathrm{~nm}$ : Size distributions and emission and coagulation rates. Environmental Science \& Technology 42, 8641-8647.

Waring, M.S., Siegel, J.A., Corsi, R.L., 2008. Ultrafine particle removal and generation by portable air cleaners. Atmospheric Environment 42, 5003-5014.

Weschler, C.J., 2003. Indoor/outdoor connections exemplified by processes that depend on an organic compound's saturation vapor pressure. Atmospheric Environment 37, 5455-5465.

Wheeler, A.J., Williams, I., Beaumont, R.A., Hamilton, R.S., 2000. Characterisation of particulate matter sampled during a study of children's personal exposure to airborne particulate matter in a UK urban environment. Environmental Monitoring and Assessment $65,69-77$.

Wigzell, E., Kendall, M., Nieuwenhuijsen, M.J., 2000. The spatial and temporal variation of particulate matter within the home. Journal of Exposure Analysis and Environmental Epidemiology 10, 307-14. 
Table 1. General description of sampling sites

\begin{tabular}{|c|c|c|c|c|}
\hline Sampling Location & $\begin{array}{l}\text { Sampling } \\
\text { Site }\end{array}$ & Sampling Space/Occupancy & Ventilation & Prominent activity \\
\hline \multirow{10}{*}{$\begin{array}{l}\text { Type I Residences } \\
(\mathbf{N}=\mathbf{5}) \\
\text { Suburban, } \\
\text { residential, lots of } \\
\text { greenery (trees), low } \\
\text { traffic, multi-storey } \\
\text { concrete buildings }\end{array}$} & \multirow{3}{*}{$\begin{array}{l}\text { House } 1 \\
3^{\text {rd }} \text { floor }\end{array}$} & $\begin{array}{l}\text { Living room (Male single) } \\
\text { carpeted }\end{array}$ & Natural & Household activities \\
\hline & & $\begin{array}{l}\text { Living room (Female single) } \\
\text { carpeted }\end{array}$ & Natural & Household activities \\
\hline & & $\begin{array}{l}\text { Kitchen (used by eight } \\
\text { students) }\end{array}$ & $\begin{array}{l}\text { Natural / } \\
\text { exhaust fan }\end{array}$ & Electricity/ cooking \\
\hline & \multirow{2}{*}{$\begin{array}{l}\text { House } 2 \\
2^{\text {nd }} \text { floor }\end{array}$} & $\begin{array}{l}\text { Living room (Male single) } \\
\text { carpeted }\end{array}$ & Natural & $\begin{array}{l}\text { Smoking, household } \\
\text { activities }\end{array}$ \\
\hline & & Kitchen (used by six students) & $\begin{array}{l}\text { Natural / } \\
\text { exhaust fan }\end{array}$ & Cooking (Electric) \\
\hline & \multirow[t]{2}{*}{$\begin{array}{l}\text { House } 3 \\
1^{\text {st }} \text { floor }\end{array}$} & $\begin{array}{l}\text { Living room (Male single) } \\
\text { carpeted }\end{array}$ & $\begin{array}{l}\text { Window } \\
\text { opening }\end{array}$ & Household activities \\
\hline & & $\begin{array}{l}\text { Kitchen (used by eight } \\
\text { students) }\end{array}$ & $\begin{array}{l}\text { Natural / } \\
\text { exhaust fan }\end{array}$ & Cooking (Electric) \\
\hline & $\begin{array}{l}\text { House } 4 \\
7^{\text {th }} \text { floor }\end{array}$ & $\begin{array}{l}\text { Living room (Male single) } \\
\text { carpeted }\end{array}$ & Natural & Household activities \\
\hline & \multirow{2}{*}{$\begin{array}{l}\text { House } 5 \\
2^{\text {nd }} \text { floor }\end{array}$} & $\begin{array}{l}\begin{array}{l}\text { Living room (Male single) } \\
\text { carpeted }\end{array} \\
\end{array}$ & Natural & $\begin{array}{l}\text { Smoking, household } \\
\text { activities }\end{array}$ \\
\hline & & Kitchen(Used by six students) & $\begin{array}{l}\text { Natural / } \\
\text { exhaust fan }\end{array}$ & Cooking (Electric) \\
\hline \multirow{4}{*}{$\begin{array}{l}\text { Type II Residences } \\
(\mathbf{N}=\mathbf{3}) \\
\text { Suburban, } \\
\text { residential, lots of } \\
\text { greenery (trees) 3- } \\
\text { storey concrete } \\
\text { buildings, low traffic } \\
\text { - except H2 (town } \\
\text { centre with high } \\
\text { traffic). }\end{array}$} & \multirow{2}{*}{$\begin{array}{l}\text { House } 1 \\
1^{\text {st }} \text { floor }\end{array}$} & $\begin{array}{l}\text { Living room } \\
\text { (Single family with one child) } \\
\text { carpeted }\end{array}$ & Natural & Household activities \\
\hline & & Kitchen & $\begin{array}{l}\text { Natural / } \\
\text { exhaust fan }\end{array}$ & Cooking (Electric) \\
\hline & $\begin{array}{l}\text { House } 2 \\
3^{\text {rd }} \text { floor }\end{array}$ & $\begin{array}{l}\text { Living room (Male single) } \\
\text { carpeted }\end{array}$ & Natural & $\begin{array}{l}\text { Smoking, household } \\
\text { activities }\end{array}$ \\
\hline & $\begin{array}{l}\text { House } 3 \\
3^{\text {rd }} \text { floor }\end{array}$ & $\begin{array}{l}\text { Living room (Shared by two } \\
\text { males and one female) }\end{array}$ & Natural & $\begin{array}{l}\text { Smoking, household } \\
\text { activities }\end{array}$ \\
\hline \multirow{5}{*}{$\begin{array}{l}\text { Type III Residences } \\
(\mathbf{N}=\mathbf{3}) \\
\text { Suburban area, lots } \\
\text { of greenery, (trees), } \\
\text { low traffic, Housing } \\
\text { fabric mostly wood } \\
\text { and concrete. }\end{array}$} & \multirow{2}{*}{$\begin{array}{l}\text { House } 1 \\
\text { Detached }\end{array}$} & $\begin{array}{l}\text { Living room, (Shared by two } \\
\text { males) carpeted }\end{array}$ & Natural & $\begin{array}{l}\text { Smoking, household } \\
\text { activities }\end{array}$ \\
\hline & & Kitchen & $\begin{array}{l}\text { Natural / } \\
\text { exhaust fan }\end{array}$ & Cooking (Gas) \\
\hline & $\begin{array}{l}\text { House } 2 \\
\text { Detached }\end{array}$ & $\begin{array}{l}\text { Living room,(Family with a } \\
\text { child) carpeted }\end{array}$ & Natural & $\begin{array}{lr}\text { Wood } & \text { burning/ } \\
\text { smoking, household } \\
\text { activities }\end{array}$ \\
\hline & \multirow{2}{*}{$\begin{array}{l}\text { House } 3 \\
\text { Detached }\end{array}$} & $\begin{array}{l}\text { Living room, Family ( } 3 \text { males } \\
\text { and } 1 \text { female) }\end{array}$ & Natural & Household activities \\
\hline & & Kitchen & $\begin{array}{l}\text { Natural / } \\
\text { exhaust fan }\end{array}$ & Cooking (Gas) \\
\hline
\end{tabular}


Table 2.Summary of 24 hour mass concentration of particulate matter $\left(\mu \mathrm{g} / \mathrm{m}^{3}\right)$ in smoking and non-smoking living rooms in type I residences during winter and summer

\begin{tabular}{|c|c|c|c|c|c|c|c|c|}
\hline & \multicolumn{4}{|c|}{ Non-smoking } & \multicolumn{4}{|c|}{ Smoking } \\
\hline & $\mathrm{PM}_{10}$ & $\mathrm{PM}_{2.5}$ & $\mathrm{PM}_{1}$ & $\begin{array}{l}\mathrm{PM}_{10}- \\
\mathrm{PM}_{2.5}\end{array}$ & $\mathrm{PM}_{10}$ & $\mathrm{PM}_{2.5}$ & $\mathrm{PM}_{1}$ & $\begin{array}{l}\mathrm{PM}_{10}- \\
\mathrm{PM}_{2.5}\end{array}$ \\
\hline \multicolumn{9}{|c|}{ Winter $(\mathrm{N} 1=20, \mathrm{~N} 2=60)$} \\
\hline Ave & $13^{\mathrm{e}}$ & $6^{f}$ & $3^{g}$ & 7 & $42^{\mathbf{a e}}$ & $37^{\text {bf }}$ & $33^{\mathrm{cg}}$ & $6^{\mathrm{d}}$ \\
\hline $\operatorname{Max}$ & 16 & 7 & 4 & 9 & 117 & 109 & 103 & 15 \\
\hline Min & 9 & 3 & 2 & 6 & 11 & 10 & 9 & 1 \\
\hline Std Dev. & 3 & 2 & 1 & 2 & 20 & 19 & 18 & 3 \\
\hline \multicolumn{9}{|c|}{ Summer $(\mathrm{N} 1=30, \mathrm{~N} 2=30)$} \\
\hline Ave & 17 & 9 & 7 & 7 & $20^{\mathrm{a}}$ & $16^{\mathbf{b}}$ & $15^{\mathrm{c}}$ & $4^{\mathrm{d}}$ \\
\hline $\operatorname{Max}$ & 22 & 15 & 12 & 8 & 33 & 29 & 26 & 5 \\
\hline Min & 12 & 4 & 2 & 6 & 8 & 6 & 5 & 2 \\
\hline Std Dev. & 4 & 4 & 4 & 1 & 8 & 8 & 7 & 1 \\
\hline
\end{tabular}

Ave (Average), Max (Maximum), Min (Minimum), Std Dev (Standard Deviation), N1 (Number of days for non- smoking), N2 (Number of days for smoking) $a, b, c, d, e, f, g$. The values with the same superscript were significantly different at the 0.05 level of significance.

Table 3. Summary of 24 hour mass concentration of particulate matter $\left(\mu \mathrm{g} / \mathrm{m}^{3}\right)$ in living rooms in type II residences

\begin{tabular}{|l|c|c|c|c|c|c|c|c|}
\hline \multirow{3}{*}{} & \multicolumn{4}{|c|}{$\begin{array}{c}\text { House with separate kitchen } \\
\text { (N= 30 days) }\end{array}$} & \multicolumn{4}{c|}{$\begin{array}{c}\text { House with open plan kitchen } \\
\text { (N=20 days) }\end{array}$} \\
\cline { 2 - 9 } & $\mathrm{PM}_{10}$ & $\mathrm{PM}_{2.5}$ & $\mathrm{PM}_{1}$ & $\mathrm{PM}_{10}-\mathrm{PM}_{2.5}$ & $\mathrm{PM}_{10}$ & $\mathrm{PM}_{2.5}$ & $\mathrm{PM}_{1}$ & $\mathrm{PM}_{10}-\mathrm{PM}_{2.5}$ \\
\hline Ave & 16 & 13 & 10 & 3 & 22 & 18 & 16 & 4 \\
\hline Max & 26 & 22 & 18 & 4 & 29 & 26 & 22 & 4 \\
\hline Min & 9 & 6 & 4 & 3 & 16 & 12 & 11 & 4 \\
\hline Std Dev & 7 & 6 & 5 & 0.49 & 7 & 7 & 6 & 0.29 \\
\hline
\end{tabular}

Ave (Average), Max (Maximum), Min (Minimum), Std Dev (Standard Deviation) 
Table 4. Summary of mass concentration of particulate matter $\left(\mu \mathrm{g} / \mathrm{m}^{3}\right)$ in living rooms (central heating and wood heating) in type III residences.

\begin{tabular}{|l|c|c|c|c|c|c|c|c|}
\hline & \multicolumn{4}{|c|}{ Central Heating $(\mathbf{N}=30)$} & \multicolumn{4}{c|}{ Wood Heating $(\mathbf{N}=10)$} \\
\hline & $\mathrm{PM}_{10}$ & $\mathrm{PM}_{2.5}$ & $\mathrm{PM}_{1}$ & $\begin{array}{l}\mathrm{PM}_{10}- \\
\mathrm{PM}_{2.5}\end{array}$ & $\mathrm{PM}_{10}$ & $\mathrm{PM}_{2.5}$ & $\mathrm{PM}_{1}$ & \begin{tabular}{l}
$\mathrm{PM}_{2.5}$ \\
\hline Ave
\end{tabular} \\
\hline $32^{\mathbf{a}}$ & $11^{\mathbf{b}}$ & $6^{\mathbf{c}}$ & 20 & $203^{\mathbf{a}}$ & $191^{\mathbf{b}}$ & $185^{\mathbf{c}}$ & 11 \\
\hline Max & 48 & 14 & 8 & 34 & 646 & 619 & 601 & 27 \\
\hline Min & 22 & 8 & 4 & 12 & 57 & 53 & 50 & 4 \\
\hline Std Dev & 10 & 2 & 1 & 8 & 201 & 193 & 188 & 9 \\
\hline
\end{tabular}

Ave (Average), Max (Maximum), Min (Minimum), Std Dev (Standard Deviation, $n$ (Number of days)

$a, b, c$. The values with the same superscript were significantly different at the 0.05 level of significance

Table 5. Summary of 24 hour mean indoor/outdoor mass concentration of particulate matter in a smoking living room in type I residences ( $\mathrm{N}=7$ days).

\begin{tabular}{|c|c|c|c|c|c|c|c|c|c|c|c|}
\hline & Indoor & Outdoor & $\mathrm{I} / \mathrm{O}$ & Indoor & Outdoor & $\mathrm{I} / \mathrm{O}$ & Indoor & Outdoor & $\mathrm{I} / \mathrm{O}$ & Indoor & Outdoor \\
\hline & $\begin{array}{c}\mathrm{PM}_{10} \\
\left(\mu \mathrm{g} / \mathrm{m}^{3}\right)\end{array}$ & $\begin{array}{c}\mathrm{PM}_{10} \\
\left(\mu \mathrm{g} / \mathrm{m}^{3}\right)\end{array}$ & $\mathrm{PM}_{10}$ & $\begin{array}{c}\mathrm{PM}_{2.5} \\
\left(\mu \mathrm{g} / \mathrm{m}^{3}\right)\end{array}$ & $\begin{array}{r}\mathrm{PM}_{2.5} \\
\left(\mu \mathrm{g} / \mathrm{m}^{3}\right)\end{array}$ & $\mathrm{PM}_{2.5}$ & $\begin{array}{c}\text { PM1 } \\
(\mu \mathrm{g} / \mathrm{m} 3)\end{array}$ & $\begin{array}{c}\mathrm{PM}_{1} \\
\left(\mu \mathrm{g} / \mathrm{m}^{3}\right)\end{array}$ & $\begin{array}{l}\mathrm{PM}_{1} \\
\left(\mu \mathrm{g} / \mathrm{m}^{3}\right)\end{array}$ & $\begin{array}{l}\mathrm{PM}_{10}-\mathrm{PM}_{2.5} \\
\left(\mu \mathrm{g} / \mathrm{m}^{3}\right)\end{array}$ & $\begin{array}{l}\mathrm{PM}_{10}-\mathrm{PM}_{2.5} \\
\left(\mu \mathrm{g} / \mathrm{m}^{3}\right)\end{array}$ \\
\hline Ave & 48 & 30 & 1.48 & 39 & 18 & 2.11 & 35 & 12 & 3.16 & 10 & 12 \\
\hline Max & 99 & 31 & 2.83 & 84 & 22 & 4.05 & 79 & 17 & 6.27 & 15 & 16 \\
\hline Min & 23 & 28 & 0.76 & 14 & 15 & 1.02 & 12 & 9 & 1.45 & 6 & 8 \\
\hline St Dev & 44 & 1 & 1.17 & 40 & 4 & 1.68 & 38 & 4 & 2.70 & 5 & 4 \\
\hline
\end{tabular}

Table 6. Summary of 24 hour mass concentration of particulate matter $\left(\mu \mathrm{g} / \mathrm{m}^{3}\right)$ in kitchens of type I, II and III residences.

\begin{tabular}{|l|c|c|c|c|c|c|c|c|c|c|c|c|}
\hline & \multicolumn{3}{|c|}{ Type I (Electric, $\mathrm{N}=50$ days) } & \multicolumn{3}{c|}{ Type II (Electric, N = 14 days) } & \multicolumn{4}{c|}{ Type III (Gas, N = 16 days) } \\
\hline & $\mathrm{PM}_{10}$ & $\mathrm{PM}_{2.5}$ & $\mathrm{PM}_{1}$ & $\begin{array}{l}\mathrm{PM}_{10}- \\
\mathrm{PM}_{2.5}\end{array}$ & $\mathrm{PM}_{10}$ & $\mathrm{PM}_{2.5}$ & $\mathrm{PM}_{1}$ & $\begin{array}{l}\mathrm{PM}_{10}- \\
\mathrm{PM}_{2.5}\end{array}$ & $\mathrm{PM}_{10}$ & $\mathrm{PM}_{2.5}$ & $\mathrm{PM}_{1}$ & $\begin{array}{c}\mathrm{PM}_{10}- \\
\mathrm{PM}_{2.5}\end{array}$ \\
\hline Ave & 63 & 56 & 51 & 7 & 59 & 46 & 37 & 13 & 30 & 10 & 5 & 20 \\
\hline Max & 135 & 130 & 122 & 14 & 146 & 130 & 108 & 19 & 58 & 23 & 11 & 35 \\
\hline Min & 26 & 20 & 18 & 2 & 23 & 13 & 7 & 6 & 16 & 5 & 2 & 11 \\
\hline Std Dev & 41 & 40 & 37 & 4 & 36 & 33 & 29 & 4 & 15 & 7 & 4 & 8 \\
\hline
\end{tabular}

Ave (Average), Max (Maximum), Min (Minimum), Std Dev (Standard Deviation). 
Table 7. Summary of number concentration $\left(\# / \mathrm{cm}^{3}\right)$ in types 1 and II residences.

\begin{tabular}{|c|c|c|c|c|}
\hline & Ave $\left(\# / \mathrm{cm}^{3}\right)$ & $\operatorname{Max}\left(\# / \mathrm{cm}^{3}\right)$ & $\operatorname{Min}\left(\# / \mathrm{cm}^{3}\right)$ & Std Dev $\left(\# / \mathrm{cm}^{3}\right)$ \\
\hline \multicolumn{5}{|l|}{ Type I residences } \\
\hline \multicolumn{5}{|c|}{ Non-smoking living rooms $(\mathrm{N}=23)$} \\
\hline 24 Hour & 11815 & 17451 & 7579 & 2692 \\
\hline Hourly maximum & 22824 & 37068 & 13179 & 7502 \\
\hline Hourly minimum & 5009 & 8512 & 1984 & 1864 \\
\hline \multicolumn{5}{|c|}{ Smoking living rooms $(\mathbf{N}=\mathbf{2 0})$} \\
\hline 24 Hour & 12891 & 17768 & 9927 & 2514 \\
\hline Hourly maximum & 47265 & 64380 & 25319 & 14090 \\
\hline Hourly minimum & 4454 & 6294 & 2785 & 1269 \\
\hline \multicolumn{5}{|c|}{ Unoccupied living room $(N=9)$} \\
\hline 24 Hour & 4003 & 7511 & 2434 & 1539 \\
\hline Hourly maximum & 9202 & 32938 & 2966 & 9244 \\
\hline Hourly minimum & 2469 & 3664 & 1661 & 693 \\
\hline \multicolumn{5}{|l|}{ Kitchen $(\mathbf{N}=16)$} \\
\hline 24 Hour & 31816 & 52787 & 13369 & 12383 \\
\hline Hourly maximum & 179110 & 502650 & 63005 & 130411 \\
\hline Hourly minimum & 4383 & 6639 & 1886 & 1449 \\
\hline \multicolumn{5}{|l|}{ Type II residences } \\
\hline \multicolumn{5}{|l|}{ Kitchen $\left(\mathrm{N}^{*}=8\right)$} \\
\hline Hourly mean & 36326 & 40142 & 32562 & 3561 \\
\hline Hourly maximum & 51598 & 52108 & 51123 & 417 \\
\hline Hourly minimum & 12741 & 16730 & 6814 & 4697 \\
\hline
\end{tabular}

Ave (Average), Max (Maximum), Min (Minimum), Std Dev (Standard Deviation), N (Number of days), $\mathrm{N}^{*}$ (periods of cooking)

Table 8. Summary of emission rates of various activities in type I residences ( $N=$ Number of occurrence of an activity)

\begin{tabular}{|l|c|c|c|l|}
\hline & $\begin{array}{l}\mathrm{PM}_{10} \\
(\mathrm{mg} / \mathrm{min})\end{array}$ & $\begin{array}{l}\mathrm{PM}_{2.5} \\
(\mathrm{mg} / \mathrm{min})\end{array}$ & $\begin{array}{l}\mathrm{PM}_{1} \\
(\mathrm{mg} / \mathrm{min})\end{array}$ & $\begin{array}{l}\text { Number } \\
\text { Concentration } \\
(\# / m i n)\end{array}$ \\
\hline Smoking $(\mathbf{N}=\mathbf{3 0})$ & & & & \\
\hline Average & 1.44 & 1.42 & 1.37 & $1.39 \mathrm{E}+11$ \\
\hline Maximum & 2.67 & 2.64 & 2.53 & $1.91 \mathrm{E}+11$ \\
\hline Minimum & 0.59 & 0.57 & 0.57 & $1.04 \mathrm{E}+11$ \\
\hline Std Dev & 0.69 & 0.70 & 0.67 & $3.87 \mathrm{E}+10$ \\
\hline Movement $(\mathbf{N}=\mathbf{2 0})$ & & & & \\
\hline Average & 0.18 & 0.002 & 0.001 & \\
\hline
\end{tabular}


Science of The Total Environment 445 (2013) pp.165-176

\begin{tabular}{|l|c|c|c|c|}
\hline Maximum & 0.26 & 0.003 & 0.000 & \\
\hline Minimum & 0.10 & 0.002 & 0.001 & \\
\hline Std Dev & 0.06 & 0.002 & 0.001 & \\
\hline Vacuuming (N = 5) & & & & \\
\hline Average & 0.69 & 0.016 & 0.000 & \\
\hline Maximum & 0.73 & 0.030 & 0.000 & \\
\hline Minimum & 0.65 & 0.008 & 0.000 & \\
\hline Std Dev & 0.03 & 0.009 & 0.000 & \\
\hline Oven grilling (N = 10) & & & \\
\hline Average & 1.88 & 1.70 & 1.49 & $4.47 \mathrm{E}+11$ \\
\hline Maximum & 2.12 & 1.93 & 1.76 & $5.39 \mathrm{E}+11$ \\
\hline Minimum & 1.50 & 1.41 & 1.21 & $3.59 \mathrm{E}+11$ \\
\hline Std Dev & 0.33 & 0.27 & 0.27 & $9.04 \mathrm{E}+10$ \\
\hline Boiling (N = 15) & & & & \\
\hline Average & 1.03 & 1.00 & 0.95 & $1.81 \mathrm{E}+11$ \\
\hline Maximum & 1.29 & 1.25 & 1.15 & $2.38 \mathrm{E}+11$ \\
\hline Minimum & 0.82 & 0.76 & 0.70 & $1.14 \mathrm{E}+11$ \\
\hline Std Dev & 0.21 & 0.21 & 0.20 & $5.50 \mathrm{E}+10$ \\
\hline Frying (N = 10) & & & & \\
\hline Average & 1.88 & 1.47 & 1.30 & $1.33 \mathrm{E}+11$ \\
\hline Maximum & 2.27 & 2.21 & 2.08 & $3.41 \mathrm{E}+11$ \\
\hline Minimum & 1.57 & 0.70 & 0.45 & $6.54 \mathrm{E}+10$ \\
\hline Std Dev & 0.35 & 0.75 & 0.82 & $9.61 \mathrm{E}+10$ \\
\hline
\end{tabular}




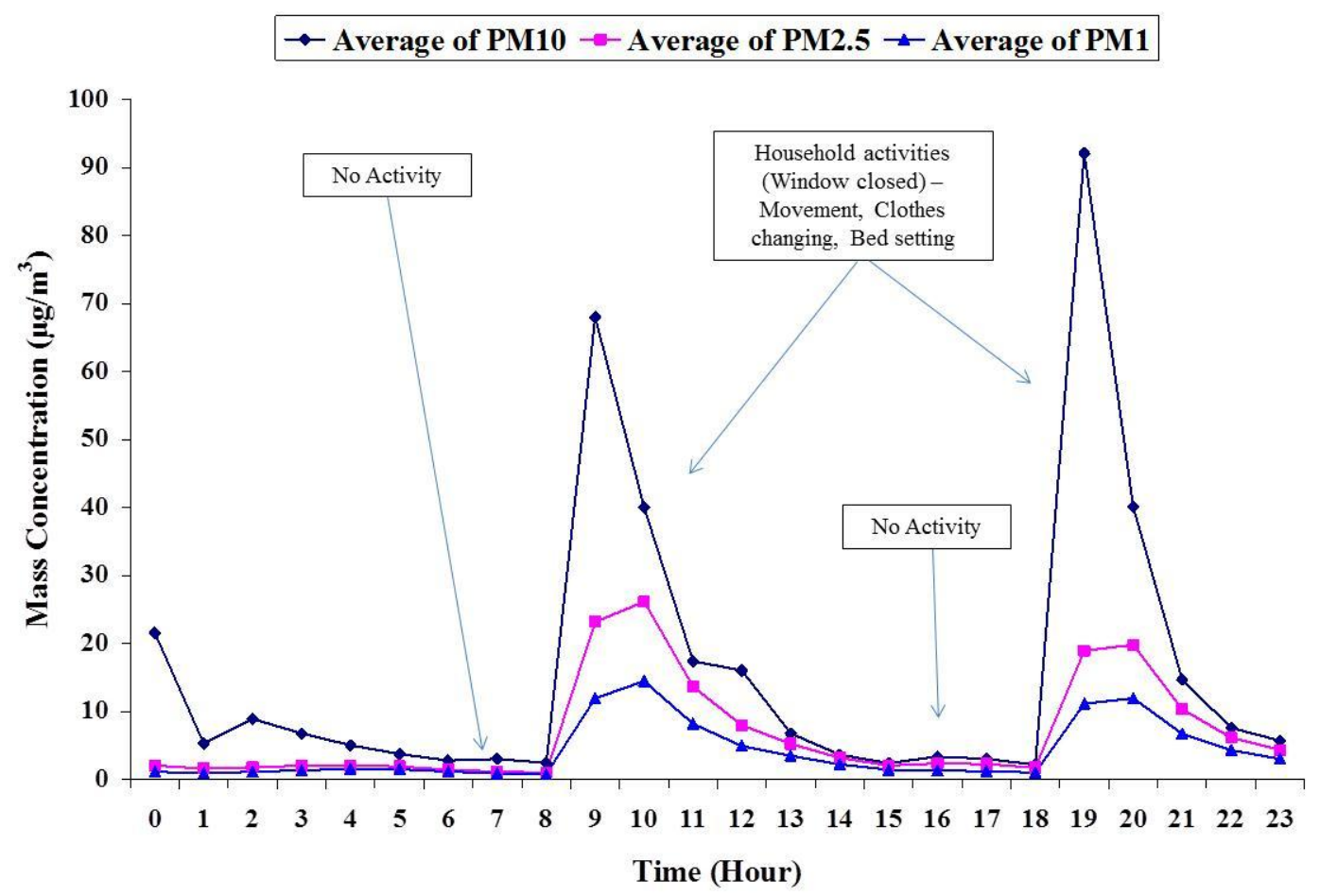

Figure 1. Representative hourly average mass concentration of $\mathrm{PM}_{10}, \mathrm{PM}_{2.5}$ and $\mathrm{PM}_{1}$ in a non-smoking living room during winter.

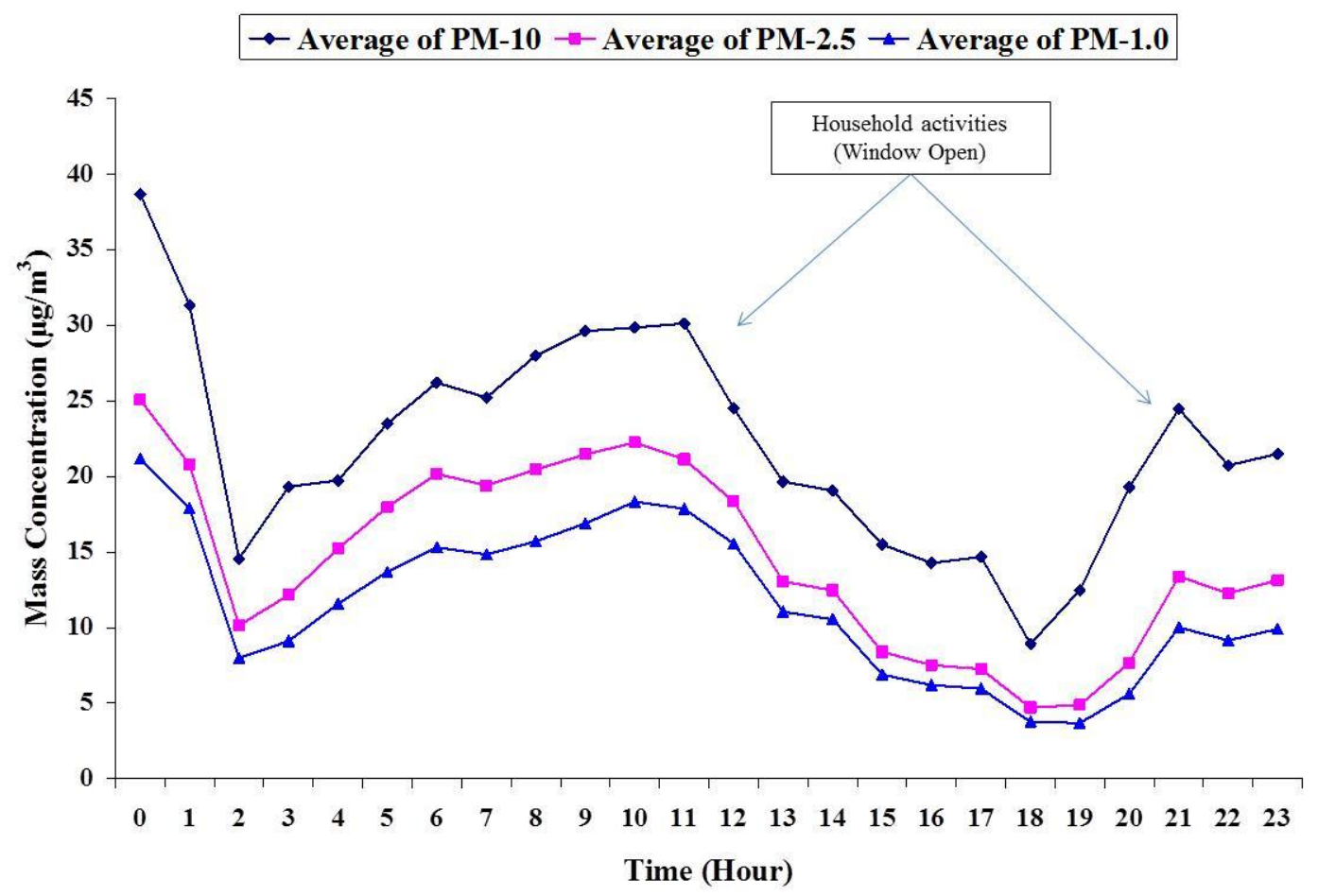

Figure 2. Representative hourly averages of mass concentration of $\mathrm{PM}_{10}, \mathrm{PM}_{2.5}$ and $\mathrm{PM}_{1}$ in a non-smoking living room during summer. 


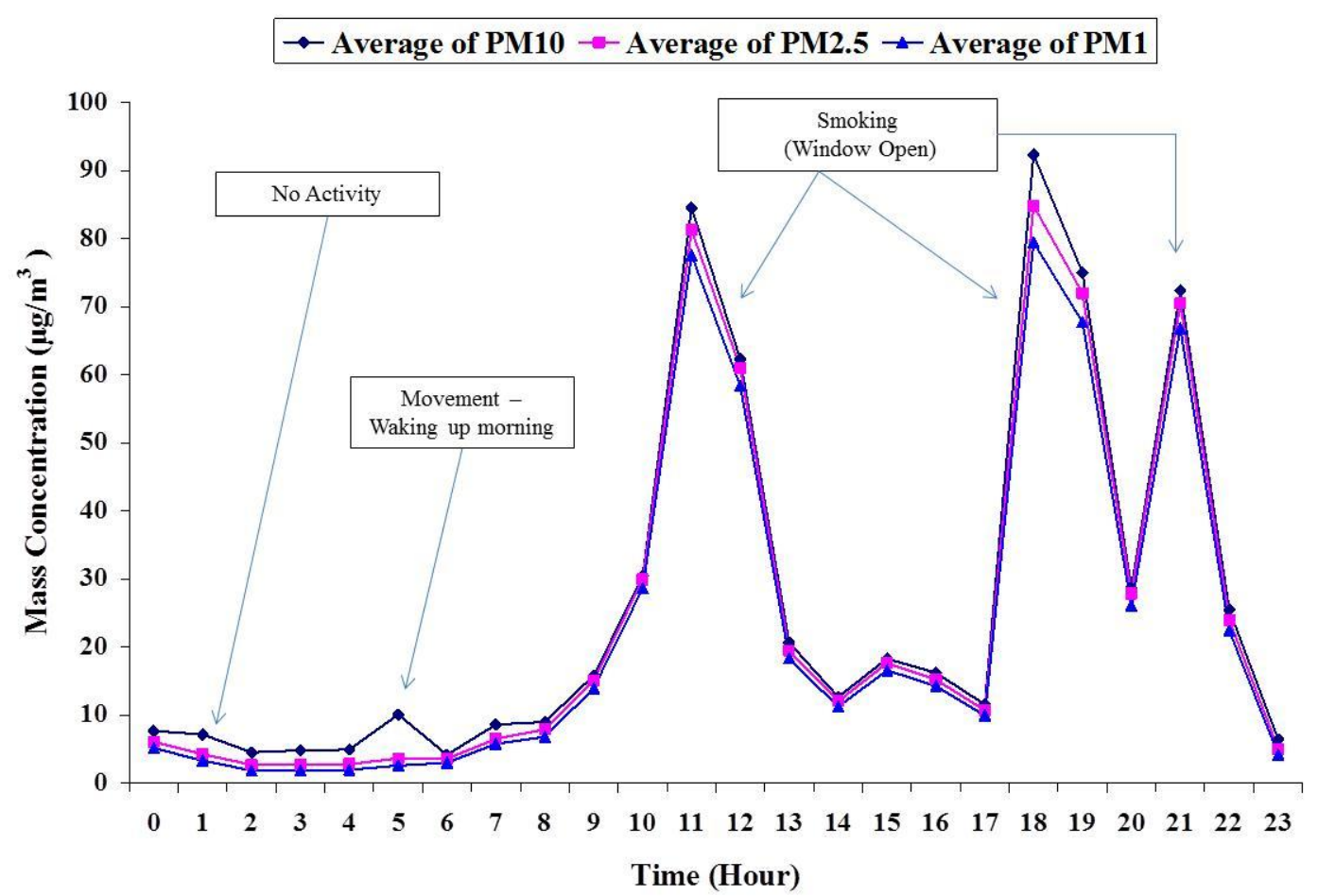

Figure 4 Representative hourly average mass concentration of $\mathrm{PM}_{10}, \mathrm{PM}_{2.5}$ and $\mathrm{PM}_{1}$ in a smoking living room during summer.

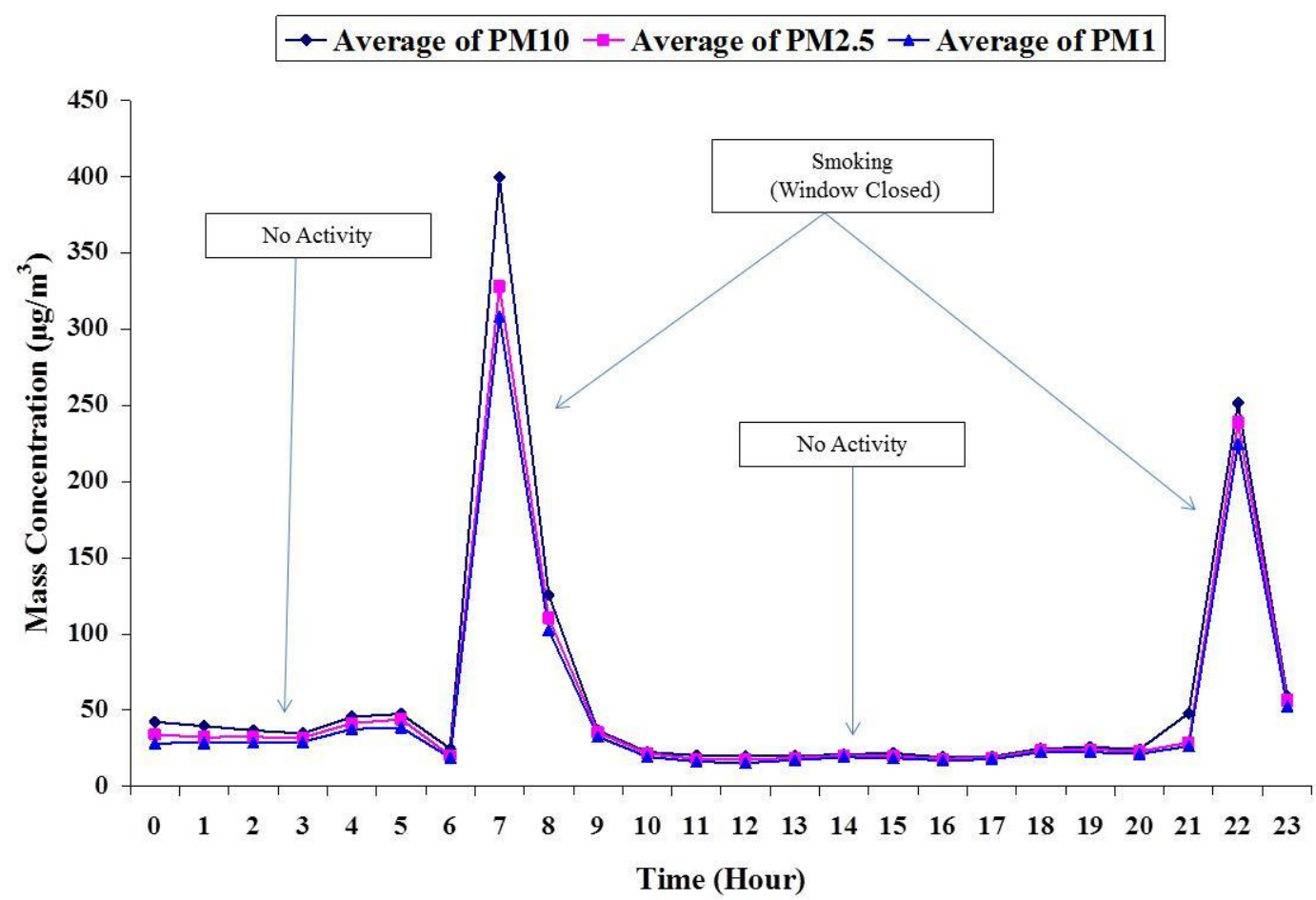

Figure 3 Representative hourly average mass concentration of $\mathrm{PM}_{10}, \mathrm{PM}_{2.5}$ and $\mathrm{PM}_{1}$ in a smoking living room during winter. 


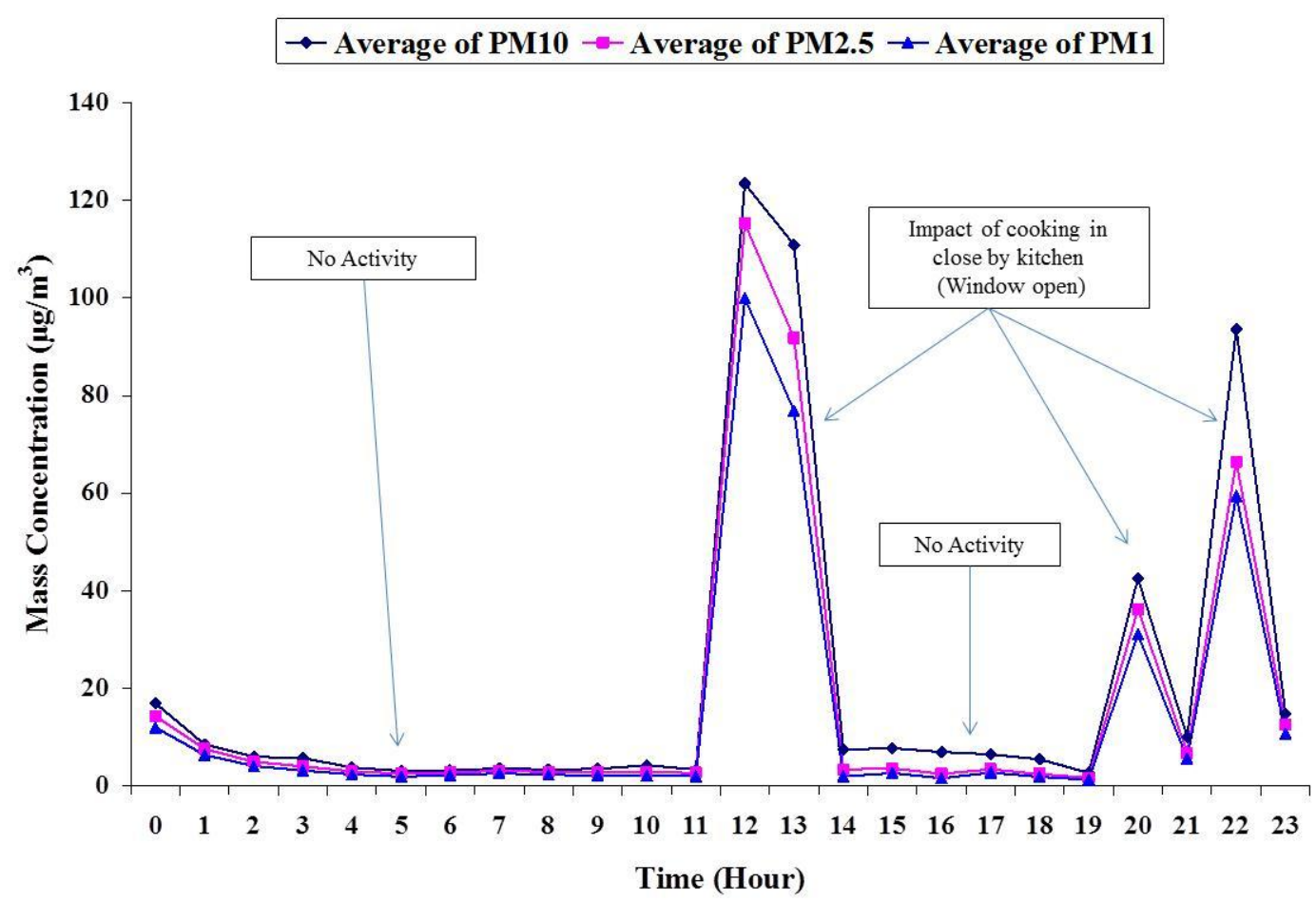

Figure 5. Representative hourly average mass concentration of $\mathrm{PM}_{10}, \mathrm{PM}_{2.5}$ and $\mathrm{PM}_{1}$ in a living room adjacent to kitchen.

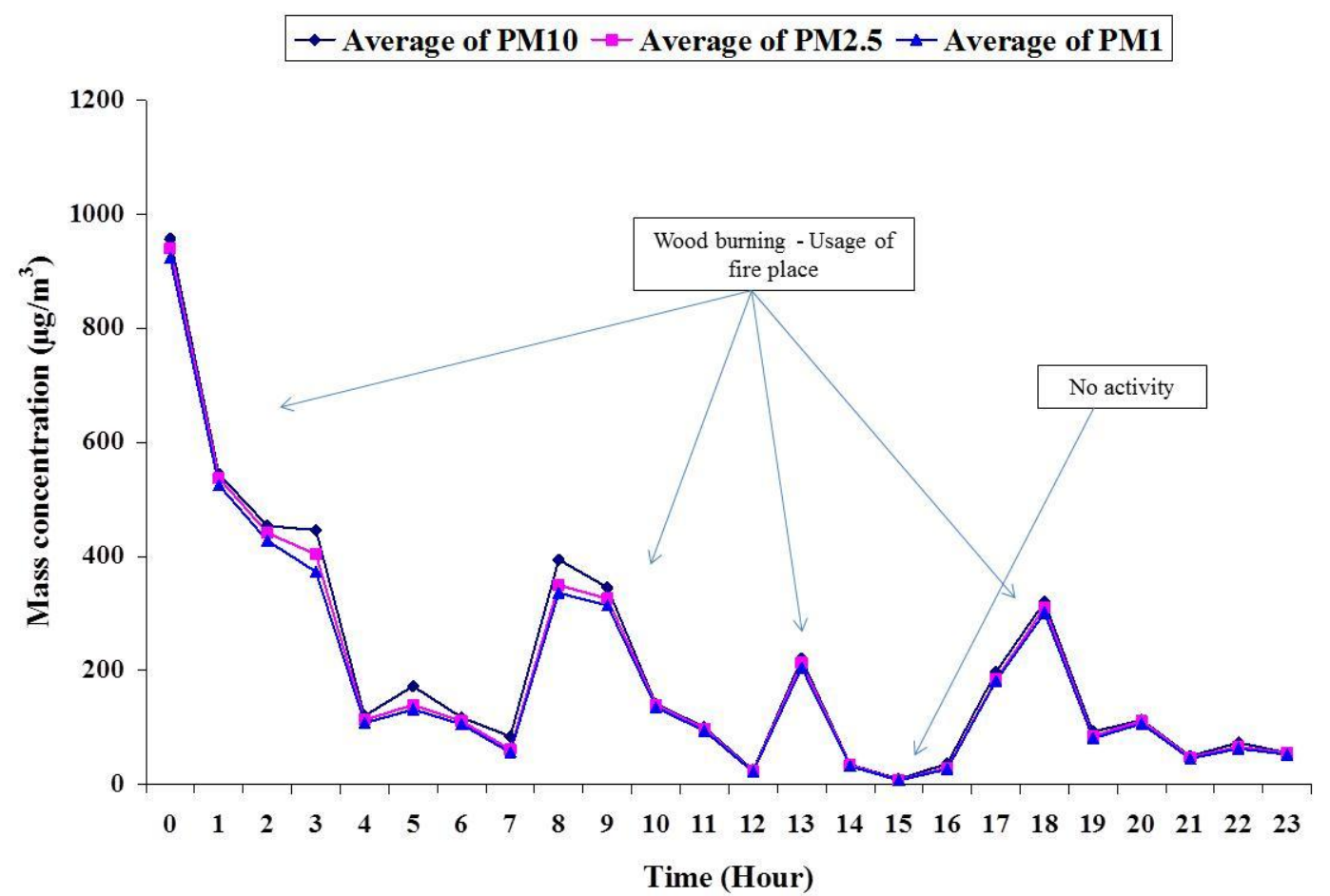

Figure 6 Representative hourly average mass concentration of $\mathrm{PM}_{10}, \mathrm{PM}_{2.5}$ and $\mathrm{PM}_{1}$ in a living room (Wood - burning) 


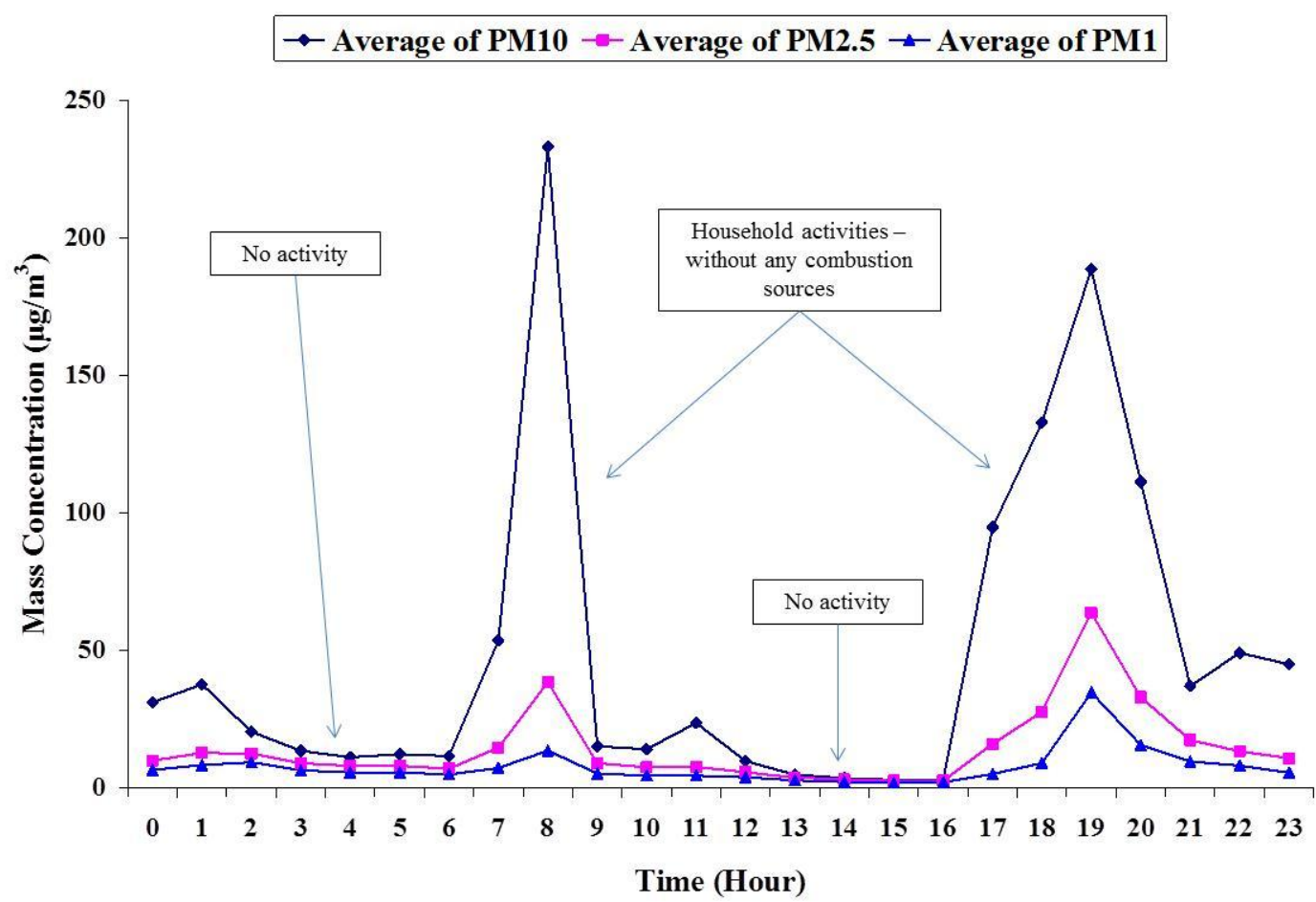

Figure 7. Representative hourly average mass concentration of $\mathrm{PM}_{10}, \mathrm{PM}_{2.5}$ and $\mathrm{PM}_{1}$ in a living room

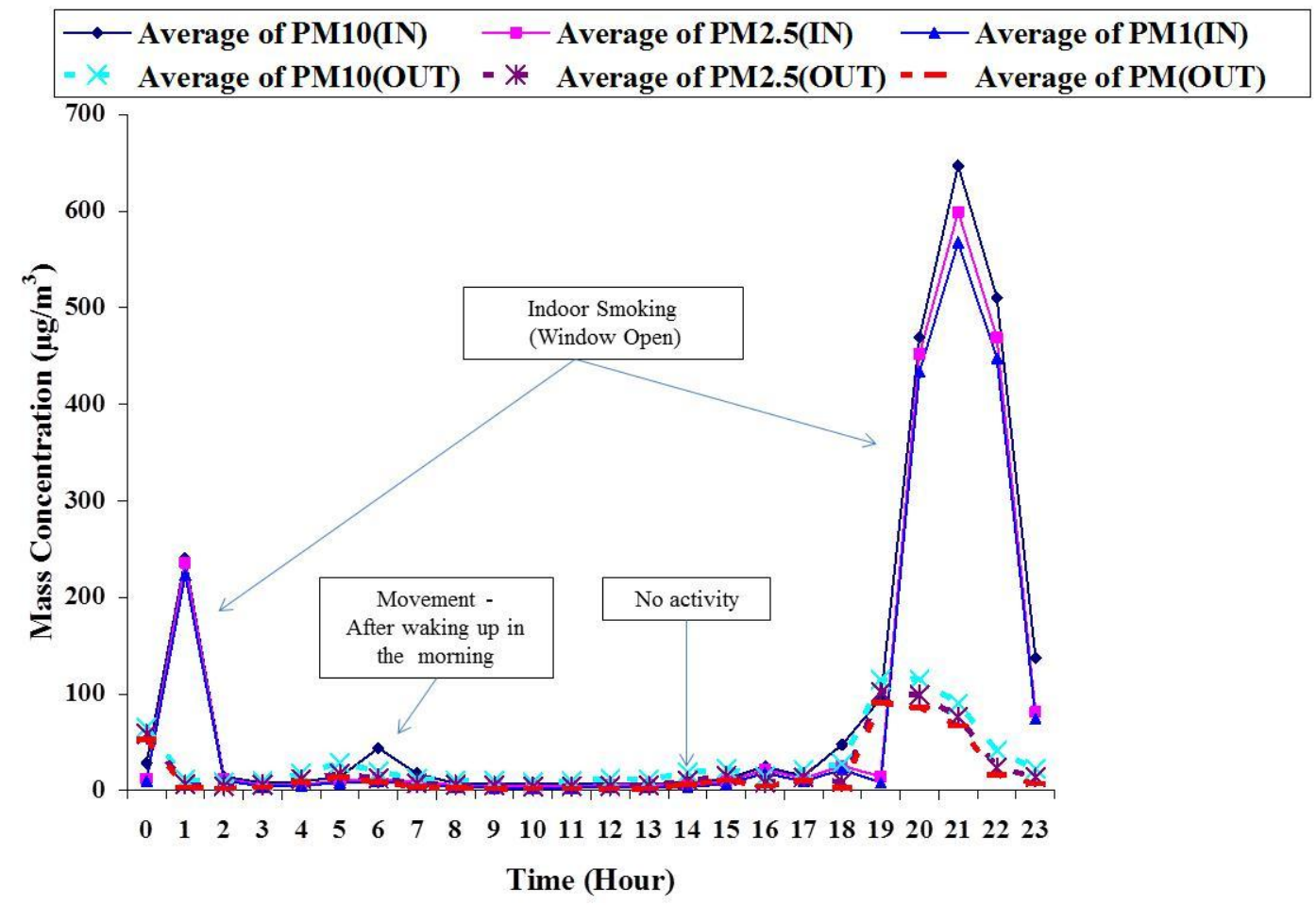

Figure 8. Representative hourly average of indoor and outdoor mass concentration for $\mathrm{PM}_{10}$, $\mathrm{PM}_{2.5}$ and $\mathrm{PM}_{1}$ in a smoking living room 


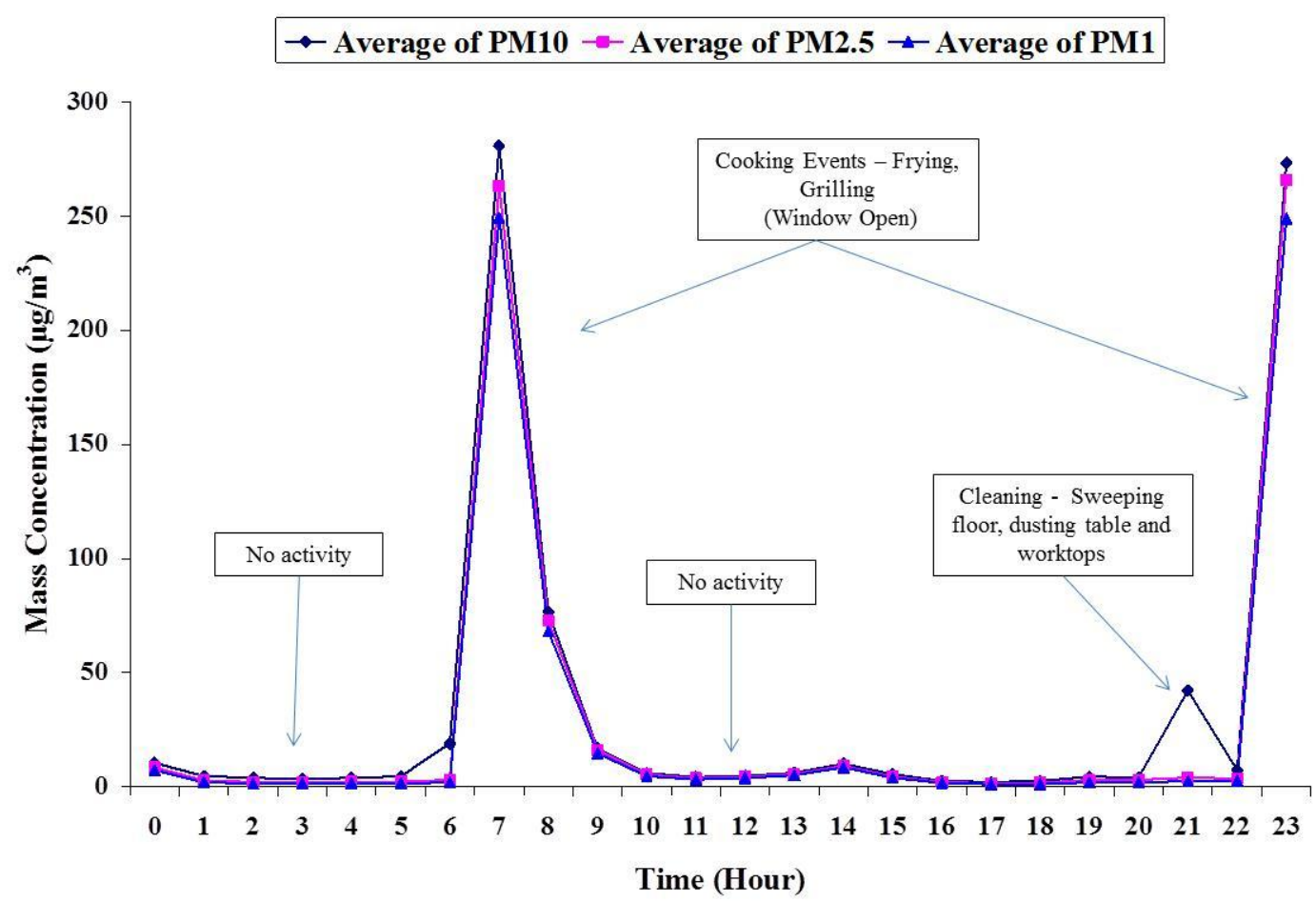

Figure 9. Representative hourly average mass concentration of $\mathrm{PM}_{10}, \mathrm{PM}_{2.5}$ and $\mathrm{PM}_{1}$ in a kitchen (electric) in type I residences.

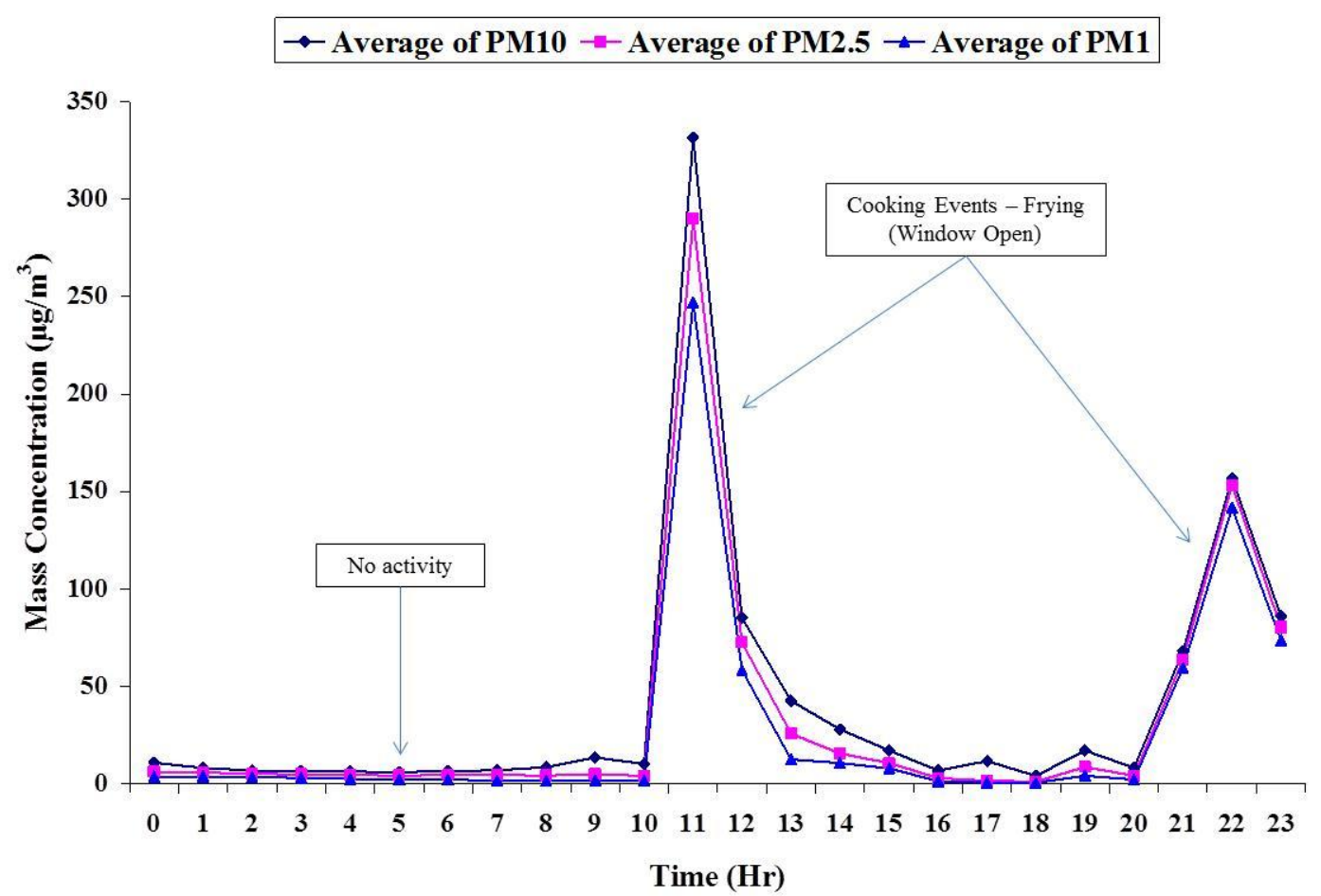

Figure 10. Representative hourly average mass concentration of $\mathrm{PM}_{10}, \mathrm{PM}_{2.5}$ and $\mathrm{PM}_{1}$ in a kitchen (electric) in type II residence 


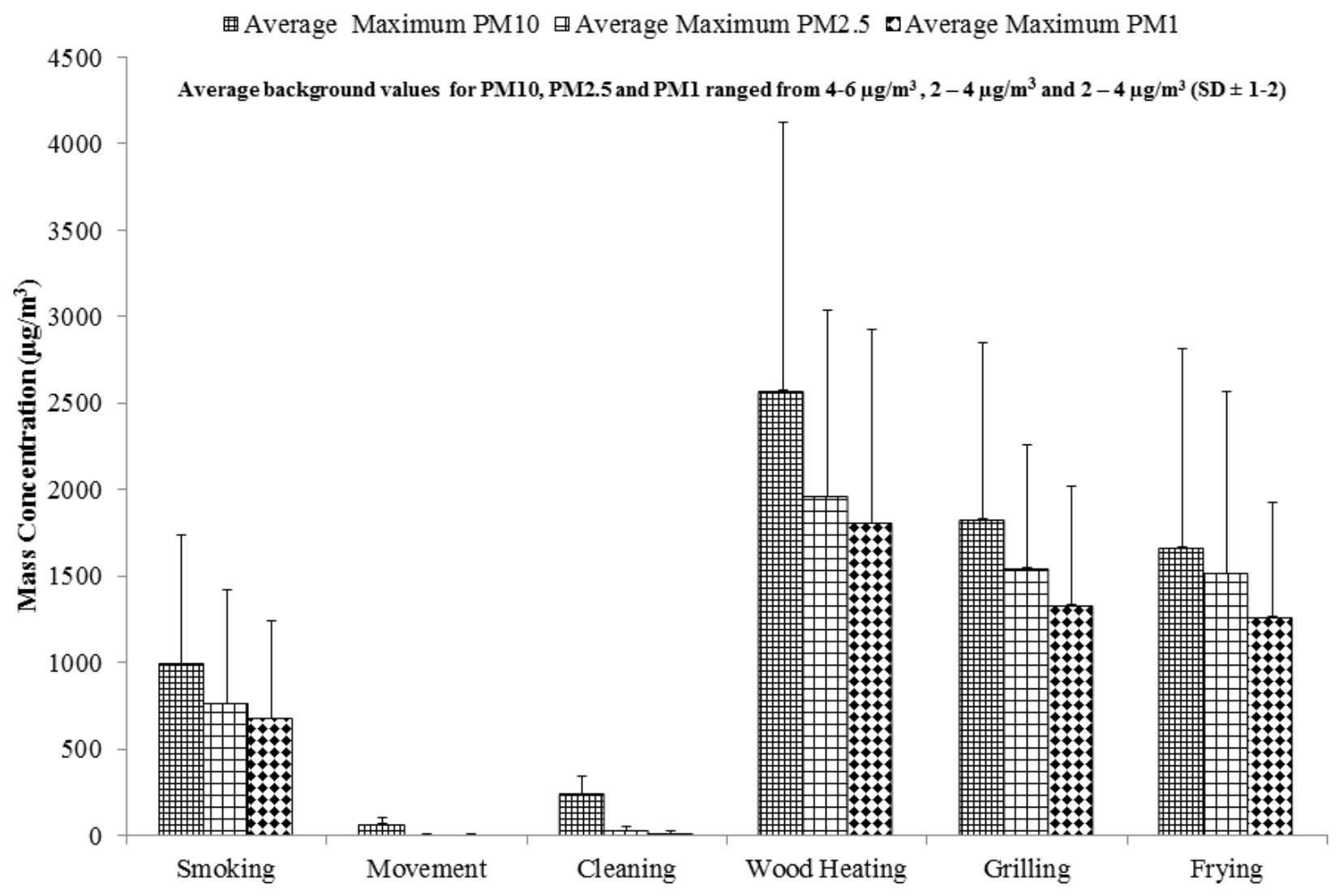

Figure 11. Average maximum concentration of $\mathrm{PM}_{10}, \mathrm{PM}_{2.5}$ and $\mathrm{PM}_{1}$ during different activities 